\title{
Physiological responses of Oxyrrhis marina to a diet of virally infected Emiliania huxleyi
}

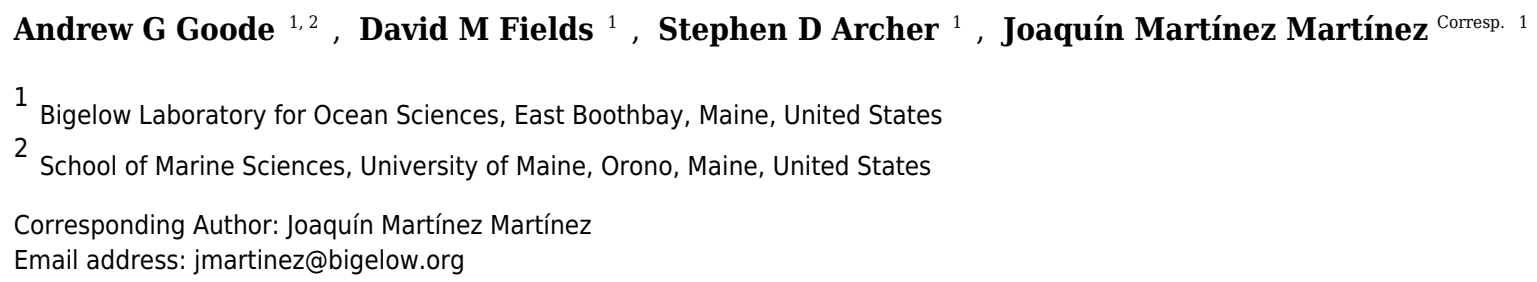

The coccolithophore Emiliania huxleyi forms some of the largest phytoplankton blooms in the ocean. The rapid demise of these blooms has been linked to viral infections. E. huxleyi abundance, distribution, and nutritional status make them an important food source for the heterotrophic protists which are classified as microzooplankton in marine food webs. In this study we investigated the fate of E. huxleyi (CCMP 374) infected with virus strain EhV86 in a simple predator-prey interaction. The ingestion rates of Oxyrrhis marina were significantly lower (between 26.9 and $50.4 \%$ ) when fed virus-infected $E$. huxleyi cells compared to non-infected cells. Despite the lower ingestion rates, O. marina showed significantly higher growth rates (between 30 and 91.3\%) when fed infected E. huxleyi cells, suggesting higher nutritional value and/or greater assimilation of infected $E$. huxleyi cells. No significant differences were found in 0 . marina cell volumes or fatty acids profiles. These results show that virally infected $E$. huxleyi support higher growth rates of single celled heterotrophs and in addition to the "viral shunt" hypothesis, viral infections may also divert more carbon to mesozooplankton grazers. 
1 Physiological responses of Oxyrrhis marina to a diet of virally infected Emiliania huxleyi

2

3 Andrew G. Goode ${ }^{1,2}$, David M. Fields ${ }^{1}$, Stephen D. Archer ${ }^{1}$, Joaquín Martínez Martínez ${ }^{1 *}$

$4 \quad{ }^{1}$ Bigelow Laboratory for Ocean Sciences, East Boothbay, ME, USA 04544

$5 \quad$ 2University of Maine, School of Marine Sciences, Orono, ME, USA 04469

6

7 *Corresponding Author. Joaquín Martínez Martínez, email: jmartinez@bigelow.org

8

9

10

11

12

13

14

15

16

17

18

19

20

21

22

23

Running Title: $O$. marina response to infected prey

Key Words: phytoplankton, zooplankton, coccolithophore, dinoflagellate, Emiliania huxleyi, Oxyrrhis marina, virus, carbon, grazing, growth, fatty acids, food web 
24 Abstract:

25

The coccolithophore Emiliania huxleyi forms some of the largest phytoplankton blooms

26 in the ocean. The rapid demise of these blooms has been linked to viral infections. E. huxleyi

27 abundance, distribution, and nutritional status make them an important food source for the

28 heterotrophic protists which are classified as microzooplankton in marine food webs. In this

29 study we investigated the fate of E. huxleyi (CCMP 374) infected with virus strain EhV-86 in a

30 simple predator-prey interaction. The ingestion rates of Oxyrrhis marina were significantly lower

31 (between 26.9 and 50.4\%) when fed virus-infected E. huxleyi cells compared to non-infected

32 cells. Despite the lower ingestion rates, O. marina showed significantly higher growth rates

33 (between 30 and 91.3\%) when fed infected E. huxleyi cells, suggesting higher nutritional value

34 and/or greater assimilation of infected E. huxleyi cells. No significant differences were found in

35 O. marina cell volumes or fatty acids profiles. These results show that virally infected E. huxleyi

36 support higher growth rates of single celled heterotrophs and in addition to the "viral shunt"

37 hypothesis, viral infections may also divert more carbon to mesozooplankton grazers. 


\section{INTRODUCTION}

Cell lysis, due to viral infection, accounts for up to $30 \%$ of daily mortality rates of marine microorganisms (Suttle 1994; van Hannen et al. 1999), influences shifts in microbial community structure (Martínez Martínez et al. 2006; Thingstad 2000), and is hypothesized to result in the reduction of infected eukaryotic phytoplankton's net primary productivity (Suttle 1994) while increasing the overall ecosystem's net primary productivity (Weitz et al. 2015). Conventional dogma holds that virus-induced cell lysis diverts energy away from the traditional food web by releasing the organic carbon $(\mathrm{C})$, nitrogen $(\mathrm{N})$, and phosphorus $(\mathrm{P})$ in phytoplankton cells to the dissolved phase, fueling an active bacterial population. This process, known as the "viral shunt", is hypothesized to transfer $6-26 \%$ of $\mathrm{C}$ (estimated 150 gigatons of $\mathrm{C}$ per year) from photosynthetic plankton to the dissolved organic pool (Suttle 2005; Wilhelm \& Suttle 1999). However, to the best of our knowledge, the magnitude of the C "shunt" during viral infection has not been directly measured. A quantitative understanding of the pathways and factors that affect the flow of organic $\mathrm{C}$ in marine systems is key to understanding community structure and for predicting resource availability to support important commercial species. Although it is known that viral infection of algal cells alters crucial cellular and biogeochemical processes (Evans et al. 2009; Gilg et al. 2016; Malitsky et al. 2016; Rosenwasser et al. 2014; Suzuki \& Suzuki 2006), the impacts of these changes on the nutritional value of cells and on the grazing and growth rates of both micro- and macrozooplankton are largely unexplored (Evans \& Wilson 2008; Vermont et al. 2016). phytoplankton species whose blooms can cover thousands of square kilometers (Holligan et al. 1993). They are a key component in pelagic food webs contributing essential amino acids and 
62 fatty acids (FA) to the base of the food chain, which are crucial for supporting multiple cellular

63 functions and growth in higher trophic level organisms. The collapse of E. huxleyi blooms have

64 been linked to infection by double-stranded (ds) DNA viruses (EhVs) (Bratbak et al. 1993;

65 Brussaard et al. 1996; Wilson et al. 2002). Infection with EhV causes rapid physiological

66 changes in E. huxleyi that divert host resources toward virus replication and assembly; e.g.,

67 decreased photochemical efficiency (Gilg et al. 2016) and altered metabolic pathways such as

68 glycolysis, FA, and nucleotide biosynthesis (Evans et al. 2009; Malitsky et al. 2016;

Rosenwasser et al. 2014). Within three hours post inoculation with EhV, E. huxleyi cultures shift from producing polyunsaturated (PUFA) to monounsaturated (MUFA) and saturated (SFA) fatty acids (Floge 2014). Additionally, viral infection can increase the uptake capacity of $\mathrm{N}$ and $\mathrm{P}$ by expressing viral genes which code for nutrient transporters not found in the host's genome and increase access to diverse nutrient sources unavailable to uninfected cells (Monier et al. 2017; Monier et al. 2012; Wilson et al. 1996). High P and/or N resources are critical for optimal viral proliferation in phytoplankton hosts (Maat \& Brussaard 2016; Maat et al. 2016; Mojica \& Brussaard 2014; Monier et al. 2017), including E. huxleyi (Bratbak et al. 1993; Martínez Martínez 2006). At the scale of large oceanic E. huxleyi blooms it remains unclear if the sum of viral alterations enhance or diminish the overall amount of $\mathrm{C}$ and essential nutrients that are passed to higher trophic levels.

Predation by heterotrophic and mixotrophic protists (microzooplankton) dominates grazing on phytoplankton in aquatic microbial food webs, and plays a key role in $\mathrm{C}$ cycling and nutrient regeneration (Calbet \& Landry 2004; Sherr \& Sherr 2002; Sherr \& Sherr 2009; Strom et al. 2001). The heterotrophic dinoflagellate Oxyrrhis marina has been shown to preferentially graze on EhV-infected E. huxleyi cells, relative to uninfected cells (Evans \& Wilson 2008). 
85 Although the mechanism driving this preferential grazing is unclear, Evans and Wilson (2008)

86

87

88

89

90

91

92

93

94

95

96

97

proposed possible changes in prey size, motility, nutritional value, palatability, and chemical cues as potential causes. However, to the best of our knowledge, those results have not yet been reproduced in any independent studies. Also, one aspect that was not investigated is if and how preferential grazing on infected E. huxleyi might modify the transfer of C and essential nutrients through the food web. In this study we investigated the effect of viral infection on the growth and ingestion rates, cell volume, and FA composition of $O$. marina cells to better understand how the grazing behavior and physiology of microzooplankton is influenced by viral infection of abundant and important phytoplankton prey.

MATERIALS AND METHODS

Culture maintenance:

Clonal Emiliania huxleyi strain CCMP 374 (non-axenic, non-calcifying; 3-5 $\mu \mathrm{m}$ ) and nonaxenic clonal O. marina strain CCMP 1795 were obtained from the Provasoli-Guillard National Center for Marine Algae and Microbiota (NCMA-Bigelow Laboratory, Maine, USA). A nonaxenic clonal Dunaliella sp. strain was sourced from the University of South Carolina. E. huxleyi, O. marina, and Dunaliella cultures were maintained at $16{ }^{\circ} \mathrm{C}$ under a light:dark cycle $\left(14: 10 \mathrm{~h} ; 250 \mu \mathrm{mol}\right.$ photons $\left.\mathrm{m}^{-2} \mathrm{~s}^{-1}\right)$. E. huxleyi and Dunaliella sp. cultures were kept in exponential growth phase by periodically transferring $10 \%(\mathrm{v} / \mathrm{v})$ culture into fresh $\mathrm{f} / 2-\mathrm{Si}$ seawater medium (Guillard 1975). Under these standard culture conditions E. huxleyi CCMP 374 cultures display near-synchronous division that starts approximately $1 \mathrm{~h}$ before the onset of the light period and last approximately $4 \mathrm{~h}$ (Gilg et al. 2016). O. marina stock cultures were fed weekly with fresh Dunaliella sp. cultures (5\% (v/v)). Fresh EhV-86 (Wilson et al. 2002) lysates were obtained by inoculating E. huxleyi cultures in exponential growth phase. Once culture 
108 clearance was observed (typically 3 - 5 days post inoculation (p.i.)), cell debris was removed by

109 filtration ( $0.45 \mu \mathrm{m}$ PES filter) and the EhV-86 lysates were then stored at $4^{\circ} \mathrm{C}$ in the dark for up

110 to two weeks prior to being used in an experiment. The same EhV-86 lysate stock was used to

111 determine infection dynamics and for grazing experiments $1-3$ (see experimental details in the

112 sections below). Cell and virus concentrations were measured using a FACScan flow cytometer

113 (Beckton Dickinson, Franklin Lakes, NJ), equipped with an air-cooled laser providing $50 \mathrm{~mW}$ at

$114488 \mathrm{~nm}$ with standard filter set-up, as previously described (Brussaard 2004; Marie et al. 1999).

115 Virus particles and bacteria cells were enumerated from $1 \mathrm{ml} 0.5 \%$ glutaraldehyde-fixed (final

116 concentration) samples that were frozen in liquid nitrogen and stored at $-80^{\circ} \mathrm{C}$ until further

117 processing. The samples were thawed and stained with SYBR Green I prior to flow cytometry

118 (FCM) enumeration. Virions and bacteria were discriminated based on green fluorescence and

119 side scatter signals (Fig. S1A). Emiliania huxleyi and O. marina cells were visualized and

120 enumerated together from fresh, non-fixed $1 \mathrm{ml} \mathrm{samples}$ by triggering the cytometer on red

121 fluorescence. Cells were enumerated based on chlorophyll red auto-fluorescence and side scatter

122 (Fig. S1B, C, D). Note that red fluorescence in fed $O$. marina cells derived from ingested prey

123 (Fig. S1C, D). Starved O. marina cells only show residual red fluorescence signal (Fig. S1B).

124 Emiliania huxleyi virus infection dynamics:

125 Fifty milliliter aliquots of exponentially growing E. huxleyi culture were inoculated at

126 four EhV-86 to host ratios of 5:1, 20:1, 50:1, and 100:1, in triplicate. The inoculations both here

127 and for experiments $1-5$ (see below) were timed to coincide with the end of the cytokinesis to

128 minimize the effect of division on the estimation of infection and grazing rates. Fresh $\mathrm{f} / 2-\mathrm{Si}$

129 media was added to each flask in order to achieve the same E. huxleyi cell concentration in all

130 flasks. One milliliter aliquots were taken from each culture at 2, 4, 6, and $20 \mathrm{~h}$ p.i. for cell 
131 enumeration using flow cytometry (FCM). Cells were stained with the orange fluorescent lipid-

132 specific dye N-(3-Triethylammoniumpropyl)-4-[4-(dibutylamino)styryl] pyridinium dibromide

133 (FM 1-43, Invitrogen Co., Carlsbad, CA, USA) to allow discrimination between visibly infected

134 and non-infected E. huxleyi cells (Martínez Martínez et al. 2011) (Fig. S2). Progression of the

135 viral infection was quantified by tracking the percentage of visibly infected E. huxleyi over time.

136 Emiliania huxleyi $C$ and $N$ content:

137 A $150 \mathrm{ml}$ volume of E. huxleyi culture in exponential growth phase was divided in two

138 equal volumes. One of the aliquots received $45 \mathrm{ml}$ EhV-86 to achieve a 50:1 virus:host ratio; the

139 second one received an equal volume of fresh $\mathrm{f} / 2-\mathrm{Si}$ medium to achieve similar cell

140 concentration in both cultures. Emiliania huxleyi concentration and percentage of visibly infected

141 cells in each flask was determined immediately after the addition of EhV-86 and f/2-Si medium

142 and at $5 \mathrm{~h}$ p.i., and at $24 \mathrm{~h}$ p.i. Six $5 \mathrm{ml}$ samples were taken from each flask immediately after the

143 addition of EhV-86 and f/2-Si medium and at $24 \mathrm{~h}$ p.i. and were gravity filtered through a

144 combusted glass fiber filter (Whatman GF/F; GE Healthcare Life Sciences, Pittsburg, PA) to

145 collect particulate matter. The filtrates were then passed through fresh combusted GF/F filters to

146 serve as $\mathrm{C}$ and $\mathrm{N}$ background controls (residual dissolved $\mathrm{C}$ and $\mathrm{N}$ retained by the filters). Filters

147 were stored at $-80^{\circ} \mathrm{C}$ until analysis. Prior to testing, the filters were dried at $45^{\circ} \mathrm{C}$ for $24 \mathrm{~h}$

148 before being placed in $9 \times 10 \mathrm{~mm}$ Costech tin capsules using clean forceps and sample

149 preparation block. Calibration standards were prepared from acetanilide. The samples, standards,

150 and filter blanks were analyzed using a Costech ECS 4010 elemental analyzer $\left(980^{\circ} \mathrm{C}\right.$

151 combustion).

152 Oxyrrhis marina specific growth and grazing rates: 
Five independent experiments (experiments $1-5$ ) were performed. Oxyrrhis marina was

154 not fed for 3 days prior to each experiment to ensure their feeding vacuoles were empty. FCM

155

156

157

158

159

160

161

162

163

164

165

166

167

168

169

170

171

172

173

174

175

was employed to check for the absence of prey-derived chlorophyll red autofluorescence signal within $O$. marina vacuoles after the 3 -day period. For experiments $1-4$, stock non-axenic $E$.

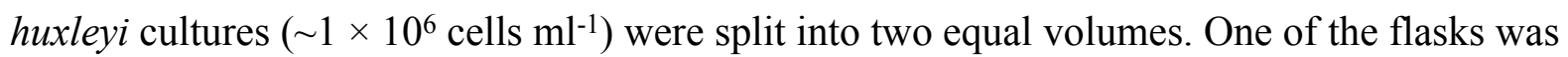
inoculated with fresh EhV-86 lysates to achieve the virus:host ratios specified for each experiment in Table 1. Incubations were carried out for $6 \mathrm{~h}$ to allow sufficient viral infection levels (see results from virus infection dynamics below, Fig.1). The second flask received f/2-Si media equal to the virus stock volume to match the dilution of cells. For experiment 5 , E. huxleyi culture was infected as described previously and was split into two equal volumes at $6 \mathrm{~h}$ p.i.. One aliquot was kept unfiltered and the other one was filtered through a $0.4 \mu \mathrm{m}$ pore size polycarbonate filter. The filter pore size was tested prior to the experiment to ensure selective removal of E. huxleyi cells ( $<1 \%$ cells passed through). Between $78 \%$ and $100 \%$ bacteria and 75-95\% EhVs were allowed through the $0.4 \mu \mathrm{m}$ filter. Experiment 5 was conducted to determine if $O$. marina growth rate is augmented or supported by ingested bacteria, virions, and/or dissolved organic matter (DOM) within the infected cultures. Non-infected diet was not included in experiment 5 .

In all experiments, the flasks were incubated without shaking under the standard culture conditions indicated above. Equal volume aliquots of either infected (including $0.4 \mu \mathrm{m}$-filtered) or non-infected E. huxleyi cultures were fed to triplicate $O$. marina cultures. Both infected and non-infected food contained bacteria; additionally, the infected food contained free EhV particles. Additional aliquots of the E. huxleyi cultures (infected and non-infected) were maintained separately as non-grazing controls. It should be noted that non-grazing control 
176 cultures were not maintained during experiment 3, instead, average $E$. huxleyi growth rates from

177 experiment 2 were used to normalize for $E$. huxleyi cell growth and lysis. Both these experiments

178 employed the same EhV stock and virus:host ratio, and only differed in the length of time of the

179 experiment (Table 1). We have shown in this study and elsewhere (Gilg et al. 2016; Vermont et

180 al. 2016) that under comparable conditions, infection dynamics and virus production are highly

181 reproducible. E. huxleyi and $O$. marina cell concentrations were monitored in each flask by

182 FCM. Prey and predator cell concentrations were measured immediately after the initial feeding

183 and every $30 \mathrm{~min}$ for the first $2 \mathrm{~h}$ and then every hour up to $6 \mathrm{~h}$ for experiment 1 (Fig. S3) and

184 every $24 \mathrm{~h}$ for experiments $2-5$. During experiments $2-5$ O. marina cultures were fed fresh

185 prey immediately after determining cell concentrations at the end of each $24 \mathrm{~h}$ incubation period

186 for a total of $3-7$ days (Table 1). The duration of our experiments are ecologically relevant and 187 representative of high rates of viral infection during induced blooms of mixed assemblies of $E$.

188 huxleyi (Castberg et al. 2001; Martínez Martínez et al. 2007). The additions of fresh prey cells 189 each day were calculated to bring the prey:predator ratio to the same level as at the beginning of

190 the experiment. Sterile $\mathrm{f} / 2-\mathrm{Si}$ medium was added, as needed, to the $O$. marina cultures to

191 maintain comparable cell concentration between treatments. Additional experimental design

192 information can be found in Table 1. Oxyrrhis marina specific growth and grazing rates were

193 determined by the equations of Frost (1972) and used to calculate $O$. marina growth per $E$.

194 huxleyi cell consumed.

195 Projected O. marina's abundance:

196 Our goal in these experiments was to maintain consistent concentration of $O$. marina and

197 E. huxleyi throughout the experiment. At each time point the cultures were sampled and high

198 concentration aliquots of fresh E. huxleyi cultures were added to replace the cells that were 
199 ingested or lost due to mortality. The concentration data with the daily dilution was used to

200 calculate the total number of $O$. marina and E. huxleyi cells that were produced and consumed,

201 respectively, over the duration of the experiment. Average growth and grazing rates of

202 individual cultures from experiments $2-4(n=9)$ were combined to calculate the overall average

$203 \pm 1$ standard error (SE) growth and grazing rates of $O$. marina fed either infected or non-infected

204 E. huxleyi cells. We postulated a starting population size of 6,000 O. marina cells and assumed

205 E. huxleyi prey saturation and no mortality for $O$. marina over a 7-day period. We applied the

206 overall $O$. marina's average \pm 1 SE growth rate over the 7-day period to calculate the cumulative

207 population size supported by infected or non-infected E. huxleyi. We then used the calculated

208 average population size of $O$. marina and its average grazing rates $( \pm 1 \mathrm{SE})$ (Frost 1972) to

209 calculate the total ingestion of E. huxleyi cells at each time point.

210

Oxyrrhis marina and E. huxleyi fatty acid (FA) analysis:

211 The effect of feeding on virally infected or non-infected $E$. huxleyi on the FA

212 composition of $O$. marina was investigated during experiment 2. For FA analysis, 5 ml aliquots

213 were taken from non-infected E. huxleyi cultures and from cultures $6 \mathrm{~h}$ after inoculation with

214 EhV-86 (in duplicate), as well as from O. marina cultures (in triplicate) before feeding them with

215 E. huxleyi cells (Day 0) and after three days being fed E. huxleyi (Day 3). Samples were vacuum

216 filtered through a combusted glass fiber filter (Whatman GF/F; GE Healthcare Life Sciences,

217 Pittsburg, PA), and stored at $-80^{\circ} \mathrm{C}$ until analysis. FAs were converted to FA methyl esters

218 (FAMEs) in a one-step extraction direct methanolysis process (Meier et al. 2006) following the

219 procedures detailed in Jacobsen et al. (2012). FAMEs were analyzed on a gas chromatograph

220 with mass spectrometric detector (Shimadzu GCMS-QP2010 Ultra, Shimadzu Scientific

221 Instruments, Columbia, MD). FAME samples were reconstituted in $200 \mu 1$ of hexane and $1 \mu 1$ 
222 was injected into the GC/MS injector which was kept at $250^{\circ} \mathrm{C}$. FAMEs were separated on a

223 SGE BPX-70 column, in a helium mobile phase at a flow rate of $1.17 \mathrm{ml} \mathrm{min}^{-1}$. A Supelco 37

224 Component FAME Mix (47885-U; Supelco Analytical, Bellefonte, PA) standard solution was

225 used for instrument calibration. Individual FAMEs were identified via comparison to standard

226 mixture peak retention times and fragmentation patterns using the NIST-library of compound

227 mass spectra. FAME concentrations were calculated from peak area relative to that of a C19:0

228 internal standard that was added to each sample prior to extraction. FA type concentrations were

229 converted to percentages of the combined total FA concentration.

230 Oxyrrhis marina cell volume:

The cell size of O. marina was measured for starved cells ( 3 days) prior to the experiment

232

233

234

235

236

237

238

239

240

241

242

243

244

and once a day for three days from each $O$. marina culture during the grazingexperiment 4 . The size of O. marina was measured on fixed cells. Common fixatives such as Lugol's or glutaraldehyde alter cell volume (Menden-Deuer et al. 2001). Alternatively, live cells can be immobilized by adding nickel sulfate $(0.003 \%$ final concentration $)$ or $70 \%$ ethanol, which appears to have no effect on cell shape and size (Menden-Deuer et al. 2001). We chose to fix $O$. marina cells by transferring $50 \%(\mathrm{v} / \mathrm{v})$ into $70 \%$ ethanol and storing at $4{ }^{\circ} \mathrm{C}$ for 30 minutes prior to analysis. Ethanol did not appear to alter cell size since our results were very similar to the measurements with added nickel sulfate from Menden-Deuer et al. (2001); however, no direct comparison of these two methods was carried out. Ten randomly selected individual O. marina cells from each aliquot were photographed on a hemocytometer. Width and length of the cells were measured using ImageJ (Schneider et al. 2012). Volume was calculated as a rotational ellipsoid; V $=\frac{\pi}{6} x d^{2} x h$ (Edler 1979; Menden-Deuer \& Lessard 2000). Differences in cell volume between treatments were evaluated using a standard t-test. Total $\mathrm{C}$ per $O$. marina cell was 
245 estimated based on the average cell volume using the equation $\log \mathrm{pg} \mathrm{C} \mathrm{cell}^{-1}=-0.665+\log$ vol

$246 \times 0.939($ Menden-Deuer \& Lessard 2000).

247 Statistical analyses:

248 Temporal differences within the same diet treatment for E. huxleyi $\mathrm{C}$ and $\mathrm{N}$ content and

249 for O. marina specific growth and ingestion rates, and cell volume were analyzed with a two-

250 tailed, paired t-test, Alpha level 0.01. When comparing parameters between treatments and for

251 FA composition, the differences were analyzed with a two-tailed, unpaired t-test assuming equal

252 variance, Alpha level 0.01. P-values $(P)<0.05$ were significant and $P<0.01$ were considered

253 highly significant.

\section{RESULTS}

255 Emiliania huxleyi virus infection dynamics:

256 The percentage of visibly infected cells (as revealed by FCM) increased at higher

257 virus:host inoculation ratios over a $20 \mathrm{~h}$ period. During this same period cell abundance did not

258 change significantly in virally-infected cultures compared to non-infected cultures (Fig. S2C).

259 The highest virus:host ratio (100:1) yielded at least20\% visibly infected E. huxleyi cells by $6 \mathrm{~h}$

260 p.i., and $\sim 57 \%$ by 20 h p.i. (Fig. 1); consequently we chose this ratio for experiments $1-3$,

261 which were carried out with the same EhV-86 stock and under the same environmental

262 conditions employed to determine the infection dynamics (Fig. 1). The infection dynamics of $E$.

263 huxleyi (CCMP374) and viral (EhV-86) production are highly consistent and reproducible when

264 using the same host and virus strains and conditions, in particular when using the same virus

265 lysate stock within a 4 week time frame (Gilg et al. 2016; Vermont et al. 2016). Infected cells

266 begin to release virus progeny at around $4.5 \mathrm{~h} \mathrm{p.i.} \mathrm{(Mackinder} \mathrm{et} \mathrm{al.} \mathrm{2009)} \mathrm{and} \mathrm{any} \mathrm{cells} \mathrm{not}$

267 infected by the initial EhV inoculum can become infected during successive infection rounds by 
268 the new EhV progeny. At the high virus:host ratios used in this study, previous work has shown

269 that $70 \%-100 \%$ of the E. huxleyi cells become infected by 24 h p.i. (Gilg et al. 2016, Vermont

270 et al. 2016), even if not evident by FCM (Martínez Martínez et al. 2011). In experiments 4 and 5,

271 we used fresh EhV-86 lysate stocks that yielded an apparent higher percentage of infected cells

272 by $6 \mathrm{~h}$ p.i. than the EhV-86 stock used in the three preceding experiments. Consequently, we

273 reduced the initial virus:host ratio to 50:1 virus:host ratio to achieve more comparable infection

274 dynamics ( $\sim 36 \%$ and $\sim 34 \%$ of E. huxleyi cells were visibly infected by 6 h p.i. in experiments 4

275 and 5, respectively).

276 Emiliania huxleyi $C$ and $N$ content:

Staining with the lipid-specific dye FM 1-43 showed $~ 15 \%$ visibly-infected E. huxleyi

278 cells by 5 h p.i. and over 70\% visibly-infected cells by 24 h p.i. Over a $24 \mathrm{~h}$ incubation, both

279 infected and non-infected cultures of E. huxleyi exhibited a slight but significant increase $(P=$

$2804.94 \times 10^{-4}$ and $P=0.018$, respectively) in $\mathrm{C}$ content of $9.27 \pm 0.19$ to $10.86 \pm 0.43$ pg C cell-1 ${ }^{-1} \pm$

$281 \mathrm{SD}$ ) for infected cells and $8.94 \pm 0.94$ to $10.42 \pm 0.26 \mathrm{pg} \mathrm{C}$ cell $^{-1}$ for non-infected cells,

282 respectively. Carbon content was not statistically different between treatments $(P=0.420$ at t0

283 and $P=0.057$ at 24 ) (Fig. 2A, Table S1). Emiliania huxleyi $\mathrm{N}$ content was not statistically

284 different between samples at the beginning of the experiment $(P=0.989)$, but it increased

285 significantly over the $24 \mathrm{~h}$ incubation; from $1.51 \pm 0.08$ to $1.89 \pm 0.13 \mathrm{pg} \mathrm{N}$ cell $^{-1}( \pm \mathrm{SD})(P=$

$\left.2866.36 \times 10^{-4}\right)$ for infected cells and $1.51 \pm 0.05$ to $2.09 \pm 0.07 \mathrm{pg} \mathrm{N}$ cell-1 $\left(P=1.80 \times 10^{-5}\right)$ for non-

287 infected cells, respectively. The $\mathrm{N}$ content of non-infected cells was significantly higher after the

28824 h incubations $(P=0.008)$ (Fig. 2B).

289 Oxyrrhis marina specific growth rate: 
longer experiments(experiments 2-4), the growth rates of $O$. marina ranged from 0.28 to 0.43

292

day $^{-1}$ (average $0.35 \pm 0.08$ day $\left.^{-1}( \pm \mathrm{SD})\right)$ when fed non-infected prey and from 0.47 to 0.56 day $^{-1}$

293 (average $0.52 \pm 0.05$ day $^{-1}$ ) when fed infected prey (Fig. 3A, Table S2). Specifically, O. marina

294

295

296

297

298

299

300

301

302

303

304

305

306

307

308

309

310

311

312

specific growth rates were $30 \%(P=0.002), 43.4 \%\left(P=5.29 \times 10^{-6}\right)$, and $91.3 \%(P=0.006)$

higher when fed infected E. huxleyi during experiments 2, 3, and 4, respectively (Fig. 3A). Based on the average growth rates, and assuming no loss term for $O$. marina cells, we calculated the abundance of $O$. marina cells after 7 days was $233 \%$ higher on a diet of infected cells than on non-infected E. huxleyi cells (Fig. 3D). In a follow up experiment (experiment 5) that measured the ingestion and growth rates of $O$. marina on infected $E$ huxleyi and bacteria, the data showed that the growth rate of $O$. marina was significantly higher $\left(P=6.49 \times 10^{-4}\right)$ when fed infected, non-axenic E. huxleyi cells (average $0.38 \pm 0.02$ day $^{-1}( \pm \mathrm{SD})$ ) than when fed $<0.4 \mu \mathrm{m}$ filtrate from infected cultures (average $0.10 \pm 0.05$ day $^{-1}( \pm \mathrm{SD})$ ) (Fig. 4A, Table S3).

\section{Oxyrrhis marina ingestion rates:}

During the initial $1.9 \mathrm{~h}$ in experiment 1, O. marina ingestions rates were not significantly

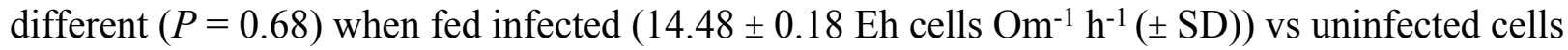
$\left(14.88 \pm 1.57 \mathrm{Eh} \mathrm{cells} \mathrm{h}^{-1}\right)$. Between 1.9 (experiment 1$)$ and $6 \mathrm{~h}$ (experiment 2$)$ no additional ingestion was measurable (Fig. 3B, Fig. S3, Table S2). Initial pulse-feeding following a period of starvation is commonly observed in grazing experiments and may explain the equal number of prey ingested in experiment $1(1.5 \mathrm{~h})$ and $2(6 \mathrm{~h})$. The combined results from grazing experiments $2-4$ yielded ingestion rates that were on average $35.4 \%$ lower $(P=0.001)$ for $O$.

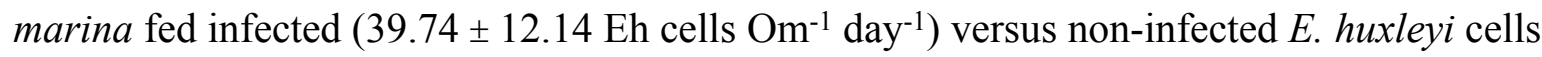
$\left(60.34 \pm 10.13 \mathrm{Eh}\right.$ cells Om $\mathrm{Om}^{-1}$ day $\left.^{-1}\right)($ Fig. 3B, Table S3). The higher total number of ingested $E$. 
313 huxleyi cells, both infected and non-infected, measured in experiments $2-4$ versus experiment

314 lindicated that $O$. marina can saturate its feeding vacuoles within the first $1.5 \mathrm{~h}$ of feeding and

315 then resumes feeding after $6 \mathrm{~h}$, as prey cells were digested. Also, the relatively low standard

316 deviation values between experiments 2-4 indicated daily ingestion rates were fairly constant

317 over time. Normalizing $O$. marina growth rate to the number of cells ingested renders differences

318 between diets $\left(P=1.60 \times 10^{-5}\right)$ even more striking (i.e., $86.30 \%, 238.62 \%$, and $154.44 \%$ higher

319 growth rate when fed infected E. huxleyi cells, for experiments 2, 3, and 4 respectively) (Fig. 3C,

320 Table S2). The elevated growth rate in of $O$. marina in the infected cultures was driven largely

321 by ingestion of E. huxleyi cells and not from ingested bacteria within the cultures (Fig 4). A

322 comparison of the growth rates of $O$. marina feeding on infected cultures showed that when the

323 E. huxylei cells were removed, O. marina growth rates decreased precipitously from $0.38 \mathrm{~d}^{-1}( \pm$

$3240.02 \mathrm{SD})$ to $0.1 \mathrm{~d}^{-1}( \pm 0.05)$ (Fig 4A). Ingestion rates of $O$. marina on infected $E$. huxleyi cells

325 were similar to experiments $2-4\left(64.98 \pm 2.72 \mathrm{Eh}\right.$ cells $\mathrm{Om}^{-1}$ day $\left.^{-1}\right)$. However, in the $<0.4 \mu \mathrm{m}$

326 filtered treatment where approximately $99 \%$ of the E. huxleyi cells were removed, the ingestion

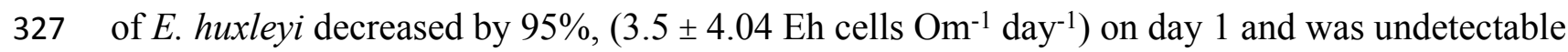

328 on the subsequent 3 days (Fig. 4B, Table S3). Conversely, the ingestion of bacteria cells (Fig 4C)

329 in the flasks with high abundance of E. huxylei cells showed low ingestion rates of bacteria on

330 day 1(262 \pm 64.51 bact cells $\mathrm{Om}^{-1}$ day $\left.^{-1}\right)$ and no detectable ingestion on the subsequent days of

331 the experiment. However, when the E huxleyi cells were removed, bacteria ingestion rates

332 increased from $767 \pm 130.35$ bact cells $\mathrm{Om}^{-1}$ day $^{-1}$ on day 1 to $3132 \pm 455.02$ bact cells Om${ }^{-1}$ day $^{-}$

$333{ }^{1}$ on day 4 . Grazing of bacteria cells was statistically different $\left(P=3.17 \times 10^{-3}\right)$ between diets on

334 day 1 (Fig. 4C, Table S3). 
the average ingestion rates (Fig. 3B), we estimated that the total consumption of virus-infected $E$.

Oxyrrhis marina and E. huxleyi fatty acid analysis:

Fatty acid (FA) profiles were similar between infected and non-infected cultures of $E$.

huxleyi (note the low SD values between the concentrations of the most abundant FAs in the

duplicate non-infected and duplicate infected E. huxleyi cultures). (Table 2). Similarly, minor

differences in the FA profile were observed in O. marina that had consumed infected versus non-

infected cells. The cultures containing O. marina fed infected E. huxleyi contained slightly

higher proportions of C17:0 and 2-fold higher proportions of C20:2 (Table 2).

346

347

348

349

350

351

352

353

354

355

356

357

\section{Oxyrrhis marina cell volume:}

The average volume of $O$. marina cells was slightly larger $(\sim 10 \%)$ when fed a diet of infected E. huxleyi prey $\left(5226 \pm 1267 \mu \mathrm{m}^{3}( \pm \mathrm{SD})\right)$ than when fed non-infected E. huxleyi $(4706 \pm$ $\left.1259 \mu \mathrm{m}^{3}\right)$. However, the difference was not statistically significant $(P=0.21)$ (Table 3, Fig. S4). While the SD were large, possibly due to the relatively low number of cells that were measured for each time point and treatment, they were similar for both diet treatments suggesting similar high volume variations between individuals in both treatments.

\section{DISCUSSION}

The results presented here show compelling evidence that virus-infected $E$. huxleyi fuels higher growth rates in the heterotrophic dinoflagellate $O$. marina. The data shows that the higher growth rates of $O$. marina resulted from ingesting fewer $E$. huxleyi cells than non-infected cells suggesting higher nutritional value of the infected E. huxleyi cells. Experiment 5 shows that the 
358 enhanced growth rates were not due to the ingestion of bacteria, virions, or DOM within the

359 infected cultures. Furthermore, the fast growing O. marina, showed similar FA profile and cell

360 size when compared to O. marina reared on non infected algae suggesting that the quality of the

361 dinoflagellates to higher trophic levels is unchanged. Consequently, the higher growth

362 efficiencies of $O$. marina feeding on virally infected $E$. huxleyi cells suggest that viral infection

363 of E. huxleyi increases the production of microzooplankton $O$. marina. These results suggest a

364 shift in the "viral shunt" paradigm in which the flow of organic matter to higher trophic levels is

365 enhanced by viral infection of algae rather than being short-circuited.

366 Oxyrrhris marina feed and grow on a wide range of protist prey types, as well as bacteria

367 (Jeong et al. 2008) and DOM (Lowe et al. 2011). However, some prey enhance growth rates

368 more than others (Montagnes et al. 2011). For example, virus-infected E. huxleyi cells supported

369 higher $O$. marina growth than non-infected $E$. huxleyi cells, despite lower ingestion rates,

370 suggesting higher nutritional value or higher assimilation efficiency of infected prey cells. It is

371 worth noting that $O$. marina ingestion rates on virally infected $E$. huxleyi cultures might have

372 been overestimated. A reduction in prey abundance due to viral lysis over each $24 \mathrm{~h}$ interval,

373 prior to fresh-prey replenishment, during the experiments might have led to temporarily reduced

374 grazer-prey encounter and ingestion rates. Under such scenario O. marina's growth per ingested

375 infected cell would have be even larger than we estimated, adding further significance to our

376 results. Consequently, our study would represent a conservative estimate of $\mathrm{C}$ transfer efficiency.

377 This study also shows that $O$. marina only ingested bacteria when $E$. huxleyi cells were not

378 available (or in very low abundance) and that ingestion of bacteria cells (and possibly EhV

379 particles and/or DOM) alone does not support high growth rates compared to E. huxleyi cells

380 even when bacteria are in very high concentrations $\left(10^{7}\right.$ cells $\left.\mathrm{ml}^{-1}\right)$. 

virally infected $E$. huxleyi cells and higher growth efficiency remain unknown. Calcification reduces digestion efficiency and predator growth (Harvey et al. 2015). In the environment, $E$. huxleyi cells lose their liths during an active viral infection (Balch et al. 1993; Brussaard et al. 1996; Frada et al. 2008; Holligan et al. 1983; Jacquet et al. 2002; Trainic et al. 2018). In this study we chose a non-calcifying E. huxleyi strain to uncouple the effects of calcification and prey size, on feeding and growth rates. Furthermore, we found no differences between $\mathrm{C}$ content in infected and non-infected E. huxleyi cells. In contrast, N content was slightly higher in noninfected cells. Nitrogen depletion in some prey cells causes $O$. marina to cease grazing, although the mechanisms remains unknown (Flynn et al. 1996; Martel 2009). However, C:N ratios in all of our E. huxleyi cultures (virus-infected or non-infected) were lower than 6.6, indicative that $\mathrm{N}$ was replete (Davidson et al. 2005; Flynn et al. 1994). Large dsDNA viruses of eukaryotic algae, such as EhVs, have a high demand of $\mathrm{C}, \mathrm{N}$ and $\mathrm{P}$ for the production of lipids, proteins, and nucleotides to support typical high burst sizes. Viral infection can modulate host metabolic pathways and nutrient uptake to fulfill the metabolic requirements of viral production (Malitsky et al. 2016; Monier et al. 2017; Monier et al. 2012; Rosenwasser et al. 2014; Wilson et al. 1996). The production of intermediary biomolecules and changes in E. huxleyi's lipidome induced by infection with EhV-86 (Evans et al. 2007; Evans et al. 2006; Evans et al. 2009; Malitsky et al. 2016; Rosenwasser et al. 2014; Suzuki \& Suzuki 2006) potentially increase the nutritional value of infected cells. During EhV infection, changes in biosynthesis pathways result in the production of more highly saturated FAs (Evans et al. 2009; Floge 2014; Malitsky et al. 2016)

402 and the enhanced production of sphingolipids (Pagarete et al. 2009; Rosenwasser et al. 2014). It 403 should be noted that the majority of these virus-induced alterations in lipid composition have 
404 been detected after prolonged infection ( $>24 \mathrm{~h}$ ) of E. huxleyi cultures. At the relatively coarse

405 level of detail in lipid profile carried out in the present study, only minor differences in FA

406 composition were observed between non-infected E. huxleyi cultures and cultures that had been

407 infected for $6 \mathrm{~h}$ (Table 2). This suggests that differences in FA composition between recently-

408 infected and non-infected E. huxleyi, were not responsible for the differences in growth rates of

409 O. marina. However, it is possible that the relatively small sample volume collected for FA

410 analysis of E. huxleyi cells limited the resolution and detection of differences in FA between

411 infected and non-infected E. huxleyi cells (Evans et al. 2009; Floge 2014; Malitsky et al. 2016).

412 Alternatively the $6 \mathrm{~h}$ time frame used in this study may be too short to measure significant

413 changes in the FA profiles of infected cells. Alterations in lipid profile between infected and non-

414 infected cells that were not apparent in our analysis (Hunter et al. 2015), may contribute to the

415 higher growth efficiencies of $O$. marina fed virally infected prey cells. An additional factor that

416 influences the nutritional value of the phytoplankton prey is $\mathrm{P}$ concentration. In addition to

417 providing a much needed resource for viral replication, P-rich phytoplankton cells increase

418 grazing efficiency and secondary production in cladocerans (Elser et al. 2001; Sterner 1993;

419 Urabe \& Sterner 1996; Urabe \& Watanabe 1992). Low P availability reduces viral replication in

420 E. huxleyi (Bratbak et al. 1993) and other eukaryotic algae (Maat et al. 2016; Wilson et al. 1996),

421 possibly by limiting the production of nucleic acids. It has been hypothesized that virally

422 encoded putative phosphate transporters increase accumulation of $\mathrm{P}$ in host cells (Monier et al.

423 2012; Wilson et al. 1996). While to the best of our knowledge this has not been tested during the

424 infection of E. huxleyi cells, most available EhV isolates, including EhV-86, carry an E. huxleyi-

425 homolog putative phosphate repressible phosphate permease (PPRPP) gene (Martínez Martínez

426 2006; Nissimov et al. 2011; Nissimov et al. 2012; Wilson et al. 2005), which we hypothesize led 
427 to higher P uptake in virally infected cells in our experiments. Additionally, the stoichiometric

428 "light:nutrient hypothesis" poses that low supply of light relative to P yields more P-rich

429 producers (i.e., low tissue C:P ratios) (Sterner et al. 1997); possibly due to the algae allocating

430 high levels of $\mathrm{P}$ to light-harvesting cellular machinery and storing excess P intracellularly

431 (Hessen et al. 2002). In our study, E. huxleyi cells were grown in P-rich f/2-Si culture medium

432 and both EhV-infected and non-infected cultures were kept under the same light conditions. In

433 addition to the role of the PPRPP gene in P uptake, we hypothesize that virus-induced reduction

434 in E. huxleyi's photochemical efficiency from the early stages of EhV infection (Gilg et al. 2016)

435 might also induce an increased $\mathrm{P}$ uptake and intracellular accumulation. While a reduction in

436 photochemical efficiency might translate into lower $\mathrm{C}$ fixation rates, our results show that $\mathrm{C}$

437 content was not affected in infected compared to non-infected cells. Phosphorus content in

438 infected and non-infected E. huxleyi cells and its impact on grazing warrants investigation in

439 future studies.

440 E. huxleyi is an important food source at the base of the food chain and grazing pressure

441 influences population and bloom dynamics (Fileman et al. 2002; Olson \& Strom 2002). Virus-

442 induced mortality also plays a prominent role in bloom demise (Bratbak et al. 1993; Brussaard et

443 al. 1996; Castberg et al. 2001; Lehahn et al. 2014; Martínez Martínez et al. 2007) and diverts

444 organic $\mathrm{C}$ away from upper trophic levels to the dissolved phase, which fuels the microbial

445 loop-“viral shunt” (Wilhelm \& Suttle 1999). Our results suggest that viral infection also boosts

446 microzooplankton production. High rates of viral infection can last from a few days (as in this

447 study) to a few weeks during a natural E. huxleyi bloom progression (Brussaard et al. 1996;

448 Castberg et al. 2001; Martínez Martínez et al. 2007), which could result in large differences in C

449 flow through the food web. Extrapolating the results in our study, the enhanced growth rates of 
450 microzooplankton populations that feed on virally infected phytoplankton cells would lead to

451 more organic $\mathrm{C}$ available for higher trophic levels. Thus, contrary to the idea that viral infection

452 leads only to the production of dissolved organic matter (Wilhelm \& Suttle 1999), viral

453 infections at the base of the food chain may augment the flow of $\mathrm{C}$ to higher trophic levels as

454 well as toward the microbial loop. To the best of our knowledge, the specific functional response

455 of copepods ingestion of $O$. marina fed infected and non-infected $E$. huxleyi has yet to be

456 investigated; however, the nutrition and reproduction rates are enhanced in copepods fed $O$.

457 marina (grown on other phytoplankton diets) compared to copepods that feed directly on small

458 phytoplankton cells (Broglio et al. 2003; Chu et al. 2008; Parrish et al. 2012; Veloza et al. 2006).

459 Phytoplankton are considered the primary producers of essential FAlong chain n-3 (LCn-3)

460 PUFAs; however, heterotrophic dinoflagellates such as $O$. marina are also able to produce

461 sterols and essential FAs (e.g., EPA (C20:5 n-3) and DHA (C22:6 n-3)) from lipid precursors

462 (Chu et al. 2008; Klein Breteler et al. 1999; Lund et al. 2008; Veloza et al. 2006), which

463 emphasizes the important role of certain microzooplankton groups in trophic upgrading and C

464 transfer and highlights the need for a better quantitative understanding of the factors that

465 influence microzooplankton grazing behavior and secondary production rates. Incorporating

466 quantitative data for viral lysis and the effect of viral infection in grazing behavior and transfer

467 efficiency into ecosystem models is essential for accurate budgeting of $\mathrm{C}$ flow throughout the

468 food web in the global marine ecosystem. As a cautionary reminder, when interpreting these

469 results it is important to note that $O$. marina is not typically found in open waters (Yang et al.

470 2011) and is not likely to be a common natural predator of E. huxleyi cells. However O. marina

471 is frequently used as a model predator in laboratory-based experiments because of its

472 morphological similarity to a wide variety of heterotrophic and mixotrophic dinoflagellates and 
473 its plasticity in feeding behavior allow it to represent a broad range of marine dominant

474 microzooplankton (Lowe et al. 2011; Roberts et al. 2011). Furthermore, several studies have

475 shown that $O$. marina responds to various experimental stimuli in similar ways to that of other

476 microzooplankton taxa (Strom et al. 2003a; Strom et al. 2003b; Tillmann 2004). E. huxleyi's true

477 protozoan predators in nature have yet to be precisely identified (Wolfe 2000).

478 A final consideration is that the lower ingestion rates of $O$. marina on E. huxleyi (strain

479 CCMP374) cells infected with coccolithovirus EhV-86, compared to non-infected cells, are in

480 contrast with an earlier study that used the same virus strain but a different E. huxleyi strain

481 (CCMP 1516-non-calcifying) (Evans \& Wilson 2008). Strain-specific differences in the

482 ingestion and clearance rates of O. marina feeding on E. huxleyi (Harvey et al. 2015) might have

483 played a role in our findings. However, in light of our findings, the results from Evans and

484 Wilson (2008) need to be revisited and revalidated and future studies should include multiple

485 strains within a species (predator, prey, and/or virus) to test differences driven by intraspecific

486 diversity. Importantly, future research is needed that focuses on a range of abundant and

487 ecologically meaningful predator-prey-virus systems.

488 CONCLUSIONS

489 Viruses cause biochemical alterations to their E. huxleyi host cells to facilitate viral assembly

490 (Gilg et al. 2016; Malitsky et al. 2016; Rosenwasser et al. 2014; Suzuki \& Suzuki 2006). The

491 data presented in this study show that changes in E. huxleyi as a result of viral infection cause

492 higher growth efficiency and an increase in heterotrophic protist production. Despite the faster

493 growth rates, we found no major difference in cell size, total FA content or FA profile of $O$.

494 marina maintained on a diet of virally infected $E$. huxleyi cells during 3 days as compared with

495 O. marina individuals reared on non-infected cells for the same period of time. Combined, these 
496 results suggest that during viral infection of E. huxleyi, the flow of $\mathrm{C}$ to higher trophic levels

497 increases. Thus, in addition to the "viral shunt" hypothesis, these results suggest that virally

498 infected E. huxleyi cells may also shunt more C to higher trophic levels . In order to gain a more

499 comprehensive understanding of ocean ecosystem webs it is essential that we get quantitative

500 knowledge of the relative magnitude of each pathway. The significance of our work is that, given

501 the global scale and rapid dynamics of viral infections in the ocean, infection of primary

502 producers is likely to be one of the compounding factors that influences the qualitative and

503 quantitative flow of $\mathrm{C}$ in oceanic systems and determines overall efficiency of transfer to higher

504 trophic levels.

505 ACKNOWLEDGEMENTS

506 We acknowledge Bigelow Analytical Services for the analysis of the fatty acid and

507 particulate carbon and nitrogen content.

508 FUNDING

509 This research was supported by funds from the National Science Foundation through

510 Grant EAR 1460861 - REU Site: Bigelow Laboratory for Ocean Sciences - Undergraduate

511 Research Experience in the Gulf of Maine and the World Ocean, Gordon and Betty Moore

512 Foundation Grant GBMF3397, and by Bigelow Laboratory for Ocean Sciences and the

513 University of Maine internal funding.

514 REFERENCES

515 Balch WM, Kilpatrick K, Holligan PM, and Cucci T. 1993. Coccolith production and

516 detachment by Emiliania huxleyi (Prymnesiophyceae). Journal of Phycology 29:566-575.

517 Bratbak G, Egge JK, and Heldal M. 1993. Viral mortality of the marine alga Emiliania

518 huxleyi (Haptophyceae) and termination of algal blooms. Mar Ecol-Prog Ser 93:39-48. 
519

520

521

522

523

524

525

526

527

528

529

530

531

532

533

534

535

536

537

538

539

540

541

Broglio E, Jónasdóttir SH, Calbet A, Jakobsen HH, and Saiz E. 2003. Effect of heterotrophic versus autotrophic food on feeding and reproduction of the calanoid copepod Acartia tonsa: relationship with prey fatty acid composition. Aquatic Microbial Ecology 31:267278.

Brussaard CPD. 2004. Optimization of procedures for counting viruses by flow cytometry. Appl Environ Microbiol 70:1506-1513.

Brussaard CPD, Kempers RS, Kop AJ, Riegman R, and Heldal M. 1996. Virus-like particles in a summer bloom of Emiliania huxleyi in the North Sea. Aquatic Microbial Ecology 10:105-113.

Calbet A, and Landry MR. 2004. Phytoplankton growth, microzooplankton grazing, and carbon cycling in marine systems. Limnology and Oceanography 49:51-57.

Castberg T, Larsen A, Sandaa RA, Brussaard CPD, Egge JK, Heldal M, Thyrhaug R, van Hannen EJ, and Bratbak G. 2001. Microbial population dynamics and diversity during a bloom of the marine coccolithophorid Emiliania huxleyi (Haptophyta). Marine EcologyProgress Series 221:39 - 46.

Chu FLE, Lund ED, and Podbesek JA. 2008. Quantitative significance of n-3 essential fatty acid contribution by heterotrophic protists in marine pelagic food webs. Marine Ecology Progress Series 354:85-95.

Davidson K, Roberts EC, Wilson AM, and Mitchell E. 2005. The Role of Prey Nutritional Status in Governing Protozoan Nitrogen Regeneration Efficiency. Protist 156:45-62. http://dx.doi.org/10.1016/j.protis.2004.10.001

Edler L. 1979. Phytoplankton and chlorophyll: Recommendations on methods for marine biological studies in the Baltic Sea. . Baltic Marine Biologists Publication 5:1-38. 
542

543

544

545

546

547

548

549

550

551

552

553

554

555

556

557

558

559

560

561

562

563

Elser JJ, Hayakawa K, and Urabe J. 2001. NUTRIENT LIMITATION REDUCES FOOD QUALITY FOR ZOOPLANKTON: DAPHNIA RESPONSE TO SESTON PHOSPHORUS ENRICHMENT. Ecology 82:898-903. 10.1890/00129658(2001)082[0898:NLRFQF]2.0.CO;2

Evans C, Kadner SV, Darroch LJ, Wilson WH, Liss PS, and Malin G. 2007. The Relative Significance of Viral Lysis and Microzooplankton Grazing as Pathways of Dimethylsulfoniopropionate (DMSP) Cleavage: An Emiliania huxleyi Culture Study. Limnology and Oceanography 52:1036-1045.

Evans C, Malin G, Mills GP, and Wilson WH. 2006. Viral infection of Emiliania huxleyi (Prymnesiophyceae) leads to elevated production of reactive oxygen species. $J$ Phycol 42:1040-1047. doi:10.1111/j.1529-8817.2006.00256.x

Evans C, Pond DW, and Wilson WH. 2009. Changes in Emiliania huxleyi fatty acid profiles during infection with E. huxleyi virus 86: physiological and ecological implications. Aquatic Microbial Ecology 55:219-228. 10.3354/ame01295

Evans C, and Wilson WH. 2008. Preferential grazing of Oxyrrhis marina on virus infected Emiliania huxleyi. Limnology and Oceanography 53:2035-2040. $10.4319 / 10.2008 .53 .5 .2035$

Fileman ES, Cummings DG, and Llewellyn CA. 2002. Microplankton community structure and the impact of microzooplankton grazing during an Emiliania huxleyi bloom, off the Devon coast. Journal of the Marine Biological Association of the United Kingdom $82: 359-368.10 .1017 / \mathrm{S} 0025315402005593$

Floge S. 2014. Virus infections of eukaryotic viruses PhD. University of Maine. 
564 Flynn KJ, Davidson K, and Cunningham A. 1996. Prey selection and rejection by a

565

566

567

568

569

570

571

572

573

574

575

576

577

578

579

580

581

582

583

584 microflagellate; implications for the study and operation of microbial food webs. Journal of Experimental Marine Biology and Ecology 196:357-372.

http://dx.doi.org/10.1016/0022-0981(95)00140-9

Flynn KJ, Davidson K, and Leftley JW. 1994. Carbon-nitrogen relations at whole-cell and free-amino-acid levels during batch growth of Isochrysis galbana (Prymnesiophyceae) under conditions of alternating light and dark. Marine Biology 118:229-237.

$10.1007 / \mathrm{bf00349789}$

Frada M, Probert I, Allen MJ, Wilson WH, and de Vargas C. 2008. The 'Cheshire Cat' escape strategy of the coccolithophore Emiliania huxleyi in response to viral infection. $P$ Natl Acad Sci USA 105:15944-15949. 10.1073/pnas.0807707105

Frost BW. 1972. Effects of size and concentration of food particles on the feeding behavior of the marine planktonic copepod Calanus pacificus. Limnology and Oceanography 17:805815. 10.4319/1o.1972.17.6.0805

Gilg IC, Archer SD, Floge SA, Fields DM, Vermont AI, Leavitt AH, Wilson WH, and Martínez Martínez J. 2016. Differential gene expression is tied to photochemical efficiency reduction in virally infected Emiliania huxleyi. Marine Ecology Progress Series 555:13-27.

Guillard RRL. 1975. Culture of phytoplankton for feeding marine invertebrates. In: Smith WL, and Chanley MH, eds. Culture of marine invertebrate animals. New York: Plenum Press, 29-60. 
585 Harvey EL, Bidle KD, and Johnson MD. 2015. Consequences of strain variability and 586 calcification in Emiliania huxleyi on microzooplankton grazing. Journal of Plankton Research 37:1137-1148. 10.1093/plankt/fbv081

Hessen DO, Færøvig PJ, and Andersen T. 2002. Light, nutrients, ans P:C ratios in algae: Grazer performance related to food quality and quantity. Ecology 83:1886-1898. 10.1890/0012-9658(2002)083[1886:LNAPCR]2.0.CO;2

Holligan PM, Fernandez E, Aiken J, Balch WM, Boyd P, Burkill PH, Finch M, Groom SB, Malin G, Muller K, Purdie DA, Robinson C, Trees CC, Turner SM, and Vanderwal P.

Holligan PM, Viollier M, Harbour DS, Camus P, and Champagnephilippe M. 1983. Satellite 596 and ship studies of coccolithophore production along a continental-shelf edge. Nature

Hunter JE, Frada MJ, Fredricks HF, Vardi A, and Van Mooy BAS. 2015. Targeted and untargeted lipidomics of Emiliania huxleyi viral infection and life cycle phases highlights

601

602

603

604 605 molecular biomarkers of infection, susceptibility, and ploidy. Frontiers in Marine Science 2. 10.3389/fmars.2015.00081

Jacobsen A, Grahl-Nielsen O, and Magnesen T. 2012. Effects of reduced diameter of bag cultures on content of essential fatty acids and cell density in a continuous algal production system. Journal of Applied Phycology 24:109-116. 10.1007/s10811-0119655-6 
606 Jacquet S, Heldal M, Iglesias-Rodriguez D, Larsen A, Wilson W, and Bratbak G. 2002. Flow 607 cytometric analysis of an Emiliana huxleyi bloom terminated by viral infection. Aquatic $608 \quad$ Microbial Ecology 27:111-124.

609 Jeong HJ, Seong KA, Yoo YD, Kim TH, Kang NS, Kim S, Park JY, Kim JS, Kim GH, and 610 Song JY. 2008. Feeding and Grazing Impact by Small Marine Heterotrophic 611 Dinoflagellates on Heterotrophic Bacteria. Journal of Eukaryotic Microbiology 55:271288. doi:10.1111/j.1550-7408.2008.00336.x

Klein Breteler WCM, Schogt N, Baas M, Schouten S, and Kraay GW. 1999. Trophic upgrading of food quality by protozoans enhancing copepod growth: role of essential lipids. Marine Biology 135:191-198. 10.1007/s002270050616 Processes to Assess the Impact of Viruses on a Mesoscale Algal Bloom. Current Biology 24:2041-2046. 10.1016/j.cub.2014.07.046

Lowe CD, Martin LE, Roberts EC, Watts PC, Wootton EC, and Montagnes DJS. 2011. Collection, isolation and culturing strategies for Oxyrrhis marina. Journal of Plankton Research 33:569-578. 10.1093/plankt/fbq161 fatty acid production in two species of heterotrophic protists: Oxyrrhis marina and Gyrodinium dominans. Marine Biology 155:23-36. 10.1007/s00227-008-1003-2 proliferation in marine phytoplankton. Aquatic Microbial Ecology 77:87-97. 
629

630

631

632

633

634

635

636

637

638

639

640

641

642

643

644

645

646

647

648

649

650
Maat DS, van Bleijswijk JDL, Witte HJ, and Brussaard CPD. 2016. Virus production in phosphorus-limited Micromonas pusilla stimulated by a supply of naturally low concentrations of different phosphorus sources, far into the lytic cycle. FEMS Microbiology Ecology 92:fiw136-fiw136. 10.1093/femsec/fiw136

Mackinder LCM, Worthy CA, Biggi G, Hall M, Ryan KP, Varsani A, Harper G, Wilson WH, Brownlee C, and Schroeder DC. 2009. A unicelular algal virus, Emiliania huxleyi virus 86, exploits an animal-like infection strategy. J Gen Virol 90:2306-2316.

Malitsky S, Ziv C, Rosenwasser S, Zheng S, Schatz D, Porat Z, Ben-Dor S, Aharoni A, and Vardi A. 2016. Viral infection of the marine alga Emiliania huxleyi triggers lipidome remodeling and induces the production of highly saturated triacylglycerol. New Phytologist 210:88-96. 10.1111/nph.13852

Marie D, Brussaard CPD, Thyrhaug R, Bratbak G, and Vaulot D. 1999. Enumeration of marine viruses in culture and natural samples by flow cytometry. Applied and Environmental Microbiology 65:45-52.

Martel CM. 2009. Conceptual Bases for Prey Biorecognition and Feeding Selectivity in the Microplanktonic Marine Phagotroph Oxyrrhis marina. Microbial Ecology 57:589-597. $10.1007 / \mathrm{s} 00248-008-9421-8$

Martínez Martínez J. 2006. Molecular ecology of marine algal viruses Ph.D. University of Plymouth.

Martínez Martínez J, Norland S, Thingstad F, Schroeder DC, Bratbak G, Wilson WH, and Larsen A. 2006. Variability in microbial population dynamics between similarly perturbed mesocosms. Journal of Plankton Research 28:783-791. 
651 Martínez Martínez J, Poulton NJ, Stepanauskas R, Sieracki ME, and Wilson WH. 2011.

652 Targeted Sorting of Single Virus-Infected Cells of the Coccolithophore $<$ italic $>$ Emiliania 653 huxleyi</italic >. PLoS ONE 6:e22520.

654 Martínez Martínez J, Schroeder DC, Larsen A, Bratbak G, and Wilson WH. 2007. Molecular 655 dynamics of Emiliania huxleyi and cooccurring viruses during two separate mesocosm studies. Appl Environ Microb 73:554-562.

657 Meier S, Mjøs SA, Joensen H, and Grahl-Nielsen O. 2006. Validation of a one-step 658 extraction/methylation method for determination of fatty acids and cholesterol in marine tissues. Journal of Chromatography a 1104:291-298. http://dx.doi.org/10.1016/j.chroma.2005.11.045

Menden-Deuer S, and Lessard EJ. 2000. Carbon to volume relationships for dinoflagellates,

Menden-Deuer S, Lessard EJ, and Satterberg J. 2001. Effect of preservation on dinoflagellate and diatom cell volume and consequences for carbon biomass predictions. Marine Ecology Progress Series 222:41-50. 515. $10.1111 / 1574-6941.12343$ AE, Derelle É, and Richards TA. 2017. Host-derived viral transporter protein for nitrogen uptake in infected marine phytoplankton. Proceedings of the National Academy of Sciences of the United States of America 114:E7489-E7498. 10.1073/pnas.1708097114 
674 Monier A, Welsh RM, Gentemann C, Weinstock G, Sodergren E, Armbrust EV, Eisen JA, 675 and Worden AZ. 2012. Phosphate transporters in marine phytoplankton and their viruses:

676

677 cross-domain commonalities in viral-host gene exchanges. Environmental Microbiology

678 $14: 162-176.10 .1111 / \mathrm{j} .1462-2920.2011 .02576 . x$

Montagnes DJS, Lowe CD, Martin L, Watts PC, Downes-Tettmar N, Yang Z, Roberts EC, and Davidson K. 2011. Oxyrrhis marina growth, sex and reproduction. Journal of Plankton Research 33:615-627. 10.1093/plankt/fbq111

Nissimov JI, Worthy CA, Rooks P, Napier JA, Kimmance SA, Henn MR, Ogata H, and Allen MJ. 2011. Draft Genome Sequence of the Coccolithovirus Emiliania huxleyi Virus 203. Journal of Virology 85:13468-13469. 10.1128/jvi.06440-11

Nissimov JI, Worthy CA, Rooks P, Napier JA, Kimmance SA, Henn MR, Ogata H, and Allen MJ. 2012. Draft Genome Sequence of the Coccolithovirus Emiliania huxleyi Virus 202. Journal of Virology 86:2380-2381. 10.1128/jvi.06863-11

Olson MB, and Strom SL. 2002. Phytoplankton growth, microzooplankton herbivory and community structure in the southeast Bering Sea: insight into the formation and temporal persistence of an Emiliania huxleyi bloom. Deep-Sea Research Part Ii-Topical Studies in Oceanography 49:5969-5990.

Pagarete A, Allen MJ, Wilson WH, Kimmance SA, and De Vargas C. 2009. Host-virus shift of the sphingolipid pathway along an Emiliania huxleyi bloom: survival of the fattest. Environmental Microbiology 11:2840-2848. 10.1111/j.1462-2920.2009.02006.x

Parrish CC, French VM, and Whiticar MJ. 2012. Lipid class and fatty acid composition of copepods (Calanus finmarchicus, C. glacialis, Pseudocalanus sp., Tisbe furcata and 
Nitokra lacustris) fed various combinations of autotrophic and heterotrophic protists.

697 Journal of Plankton Research 34:356-375. 10.1093/plankt/fbs003

698

699

700

701

702

703

704

705

706

707

708

709

710

711

712

713

714

715

716

717
Roberts EC, Wootton EC, Davidson K, Jeong HJ, Lowe CD, and Montagnes DJS. 2011.

Feeding in the dinoflagellate Oxyrrhis marina: linking behaviour with mechanisms. Journal of Plankton Research 33:603-614. 10.1093/plankt/fbq118

Rosenwasser S, Mausz MA, Schatz D, Sheyn U, Malitsky S, Aharoni A, Weinstock E, Tzfadia O, Ben-Dor S, Feldmesser E, Pohnert G, and Vardi A. 2014. Rewiring Host Lipid Metabolism by Large Viruses Determines the Fate of Emiliania huxleyi, a BloomForming Alga in the Ocean. The Plant Cell Online 26:2689-2707.

10.1105/tpc.114.125641

Schneider CA, Rasband WS, and Eliceiri KW. 2012. NIH Image to ImageJ: 25 years of image analysis. Nat Meth 9:671-675.

Sherr EB, and Sherr BF. 2002. Significance of predation by protists in aquatic microbial food webs. Antonie Van Leeuwenhoek International Journal of General and Molecular Microbiology 81:293-308. 10.1023/a:1020591307260

Sherr EB, and Sherr BF. 2009. Capacity of herbivorous protists to control initiation and development of mass phytoplankton blooms. Aquatic Microbial Ecology 57:253-262.

Sterner RW. 1993. Daphnia Growth on Varying Quality of Scenedesmus: Mineral Limitation of Zooplankton. Ecology 74:2351-2360. 10.2307/1939587

Sterner RW, Elser JJ, Fee EJ, Guildford SJ, and Chrzanowski TH. 1997. The Light: Nutrient Ratio in Lakes: The Balance of Energy and Materials Affects Ecosystem Structure and Process. The American Naturalist 150:663-684. 10.1086/286088 
718

719

720

721

722

723

724

725

726

727

728

729

730

731

732

733

734

735

736

737

738

739

740

Strom S, Wolfe G, Holmes J, Stecher H, Shimeneck C, and Sarah L. 2003a. Chemical defense in the microplankton I: Feeding and growth rates of heterotrophic protists on the DMSproducing phytoplankter Emiliania huxleyi. Limnology and Oceanography 48:217-229. 10.4319/1o.2003.48.1.0217

Strom S, Wolfe G, Slajer A, Lambert S, and Clough J. 2003b. Chemical defense in the microplankton II: Inhibition of protist feeding by $\beta$-dimethylsulfoniopropionate (DMSP). Limnology and Oceanography 48:230-237. 10.4319/1o.2003.48.1.0230

Strom SL, Brainard MA, Holmes JL, and Olson MB. 2001. Phytoplankton blooms are strongly impacted by microzooplankton grazing in coastal North Pacific waters. Marine Biology 138:355-368.

Suttle C. 2005. Viruses in the sea. Nature 437:356 - 361.

Suttle CA. 1994. The Significance of Viruses to Mortality in Aquatic Microbial Communities. Microbial Ecology 28:237-243.

Suzuki T, and Suzuki Y. 2006. Virus Infection and Lipid Rafts. Biological and Pharmaceutical Bulletin 29:1538-1541. 10.1248/bpb.29.1538

Thingstad TF. 2000. Elements of a theory for the mechanisms controlling abundance, diversity, and biogeochemical role of lytic bacterial viruses in aquatic systems. Limnol Oceanogr 45:1320-1328.

Tillmann U. 2004. Interactions between Planktonic Microalgae and Protozoan Grazers1. Journal of Eukaryotic Microbiology 51:156-168. 10.1111/j.1550-7408.2004.tb00540.x

Trainic M, Koren I, Sharoni S, Frada M, Segev L, Rudich Y, and Vardi A. 2018. Infection Dynamics of a Bloom-Forming Alga and Its Virus Determine Airborne Coccolith Emission from Seawater. iScience 6:327-335. 10.1016/j.isci.2018.07.017 
741

742

743

744

745

746

747

748

749

750

751

752

753

754

755

756

757

758

759

760

761

762

763

Urabe J, and Sterner RW. 1996. Regulation of herbivore growth by the balance of light and nutrients. Proceedings of the National Academy of Sciences 93:8465-8469.

Urabe J, and Watanabe Y. 1992. Possibility of N or P limitation for planktonic cladocerans: An experimental test. Limnology and Oceanography 37:244-251.

$10.4319 / 10.1992 .37 .2 .0244$

van Hannen EJ, Zwart G, van Agterveld MP, Gons HJ, Ebert J, and Laanbroek HJ. 1999.

Changes in bacterial and eukaryotic community structure after mass lysis of filamentous cyanobacteria associated with viruses. Applied and Environmental Microbiology 65:795801.

Veloza AJ, Chu F-LE, and Tang KW. 2006. Trophic modification of essential fatty acids by heterotrophic protists and its effects on the fatty acid composition of the copepod Acartia tonsa. Marine Biology 148:779-788. 10.1007/s00227-005-0123-1

Vermont A, Martínez Martínez J, Waller J, Gilg I, Leavitt A, Floge S, Archer S, Wilson W, and Fields D. 2016. Virus infection of Emiliania huxleyi deters grazing by the copepod Acartia tonsa. Journal of Plankton Research 38:1194-1205. 10.1093/plankt/fbw064

Weitz JS, Stock CA, Wilhelm SW, Bourouiba L, Coleman ML, Buchan A, Follows MJ, Fuhrman JA, Jover LF, Lennon JT, Middelboe M, Sonderegger DL, Suttle CA, Taylor BP, Frede Thingstad T, Wilson WH, and Eric Wommack K. 2015. A multitrophic model to quantify the effects of marine viruses on microbial food webs and ecosystem processes. The Isme Journal 9:1352. 10.1038/ismej.2014.220 https:/www.nature.com/articles/ismej2014220\#supplementary-information Wilhelm SW, and Suttle CA. 1999. Viruses and nutrient cycles in the sea. Viruses play critical roles in the structure and function of aquatic food webs. Bioscience 49:781-788. 
764 Wilson WH, Carr NG, and Mann NH. 1996. The effect of phosphate status on the kinetics of 765 cyanophage infection in the oceanic cyanobacterium Synechococcus sp WH7803. Journal

766

767

768

769

770

771

772

773

774

775

776 of Phycology 32:506-516.

Wilson WH, Schroeder DC, Allen MJ, Holden M, Parkhill J, Barrell BG, Churcher C, Hamlin N, Mungall K, Norbertczak H, Quail MA, Price CC, Rabbinowitsch E, Walker D, Craigon M, Roy D, and Ghazal P. 2005. Complete genome sequence and lytic phase transcription profile of a Coccolithovirus. Science 309:1090-1092.

Wilson WH, Tarran GA, Schroeder D, Cox M, Oke J, and Malin G. 2002. Isolation of viruses responsible for the demise of an Emiliania huxleyi bloom in the English Channel. $J$ Mar Biol Assoc UK 82:369-377.

Yang Z, Jeong HJ, and Montagnes DJS. 2011. The role of Oxyrrhis marina as a model prey: current work and future directions. Journal of Plankton Research 33:665-675. 10.1093/plankt/fbq112 
Figure 1

Infection progression of E. huxleyi

Fig. 1. Infection progression of $E$. huxleyi at four different virus:host ratios; 5:1( $\mathbf{\Lambda}), 20: 1(\bullet)$, 50:1 (ם), and 100:1 (@). Values are mean percentage (\%) of cells visibly infected over time (hours) \pm one standard deviation.

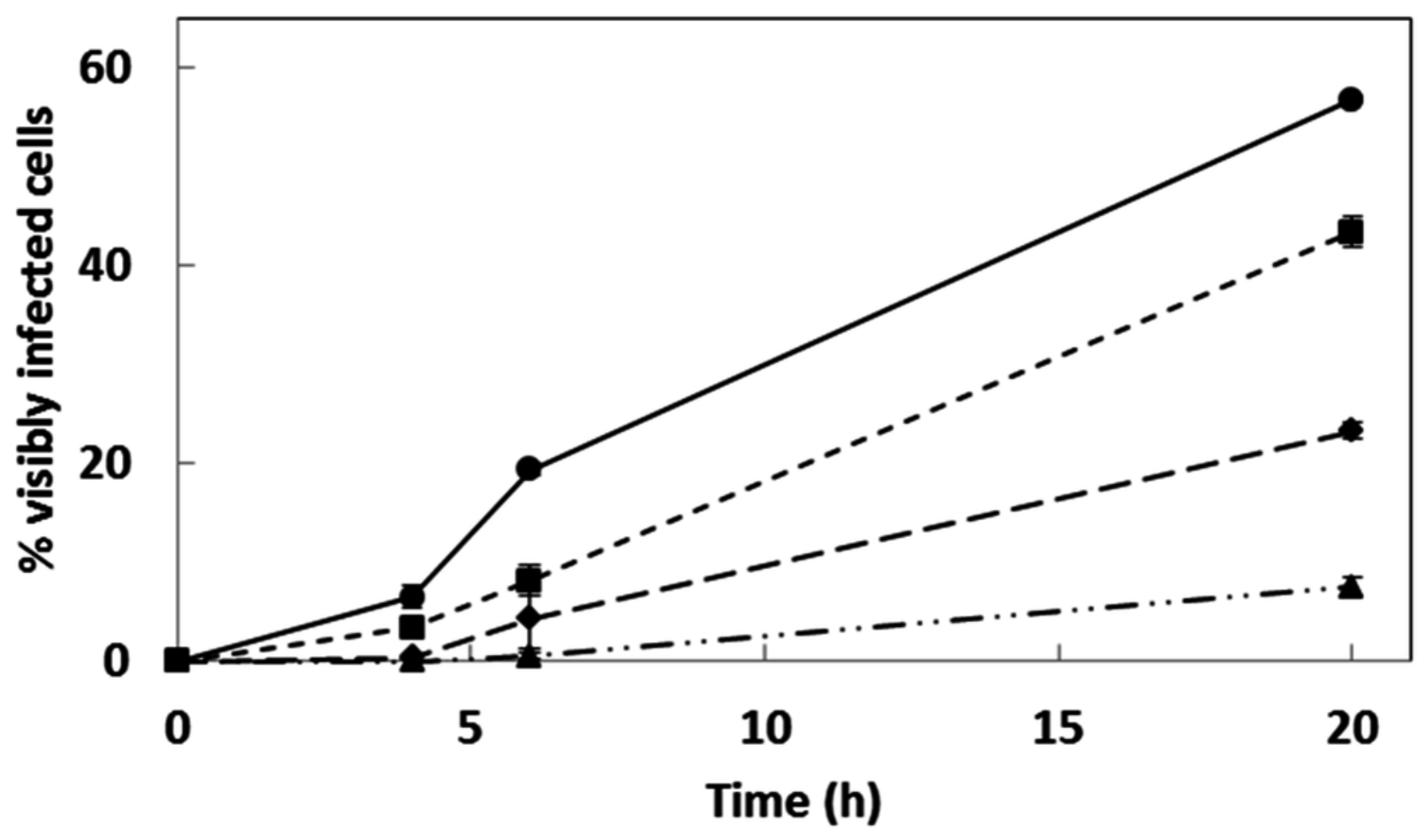




\section{Figure 2}

E. huxleyi $\mathrm{C}$ and $\mathrm{N}$ concentration

Fig. 2. E. huxleyi $\mathrm{C}(\mathbf{A})$ and $\mathrm{N}(\mathbf{B})$ concentration (pg cell ${ }^{-1}$ ) at 0 and 24 hours p.i. Values are mean \pm one standard deviation. Letters indicate statistical similarity. Same letters indicate no statistical difference between compared treatments and different letters denote significant statistical differences.
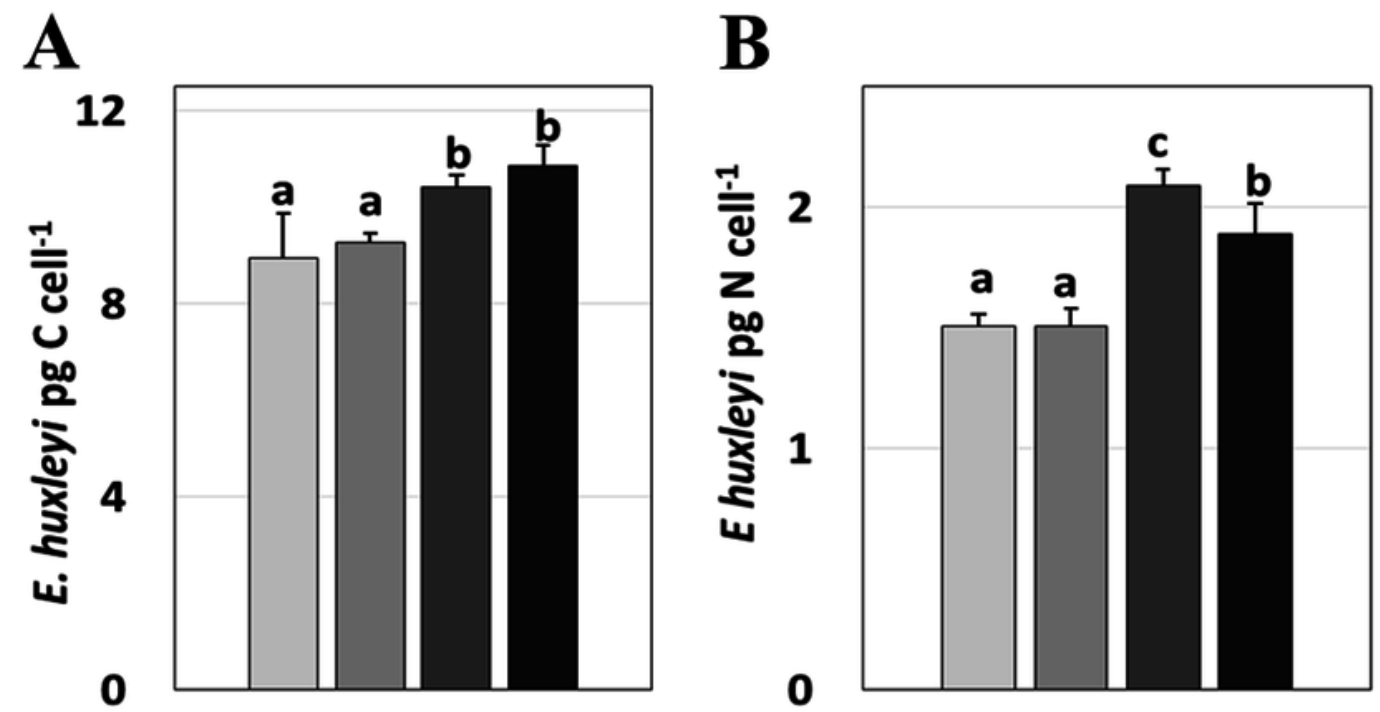

TO: Eh non-inf $\square$ TO: Eh inf

-T24: Eh non-inf

-T24: Eh inf 


\section{Figure 3}

Growth and grazing rates

Fig. 3. Differential growth and grazing rates of $O$. marina fed non-infected versus infected $E$. huxleyi. A: O. marina growth rates (day ${ }^{-1}$ ). B: O. marina grazing rates (Eh cells $\mathrm{Om}^{-1} \mathrm{~h}^{-1}$ (Exp. 1) or Eh cells $\mathrm{Om}^{-1}$ day $^{-1}$ (Exps. 2-4); see Table 1). C: 0 . marina growth rate divided by grazing rate ( $O$. marina divided per $E$. huxleyi consumed). Values mean \pm one standard deviation (Experiments 2, 3, and 4) and standard deviation (Experiment 1). D: Projected $O$. marina's population size at each time point. E: Projected total consumption of $E$. huxleyi cells at each time point. Dashed lines are average values and shaded regions are one standard error from Experiments 2, 3, and 4. Asterisks indicate statistical significance: $* * * p<0.001$, $* * p<0.01, * p<0.05$. 

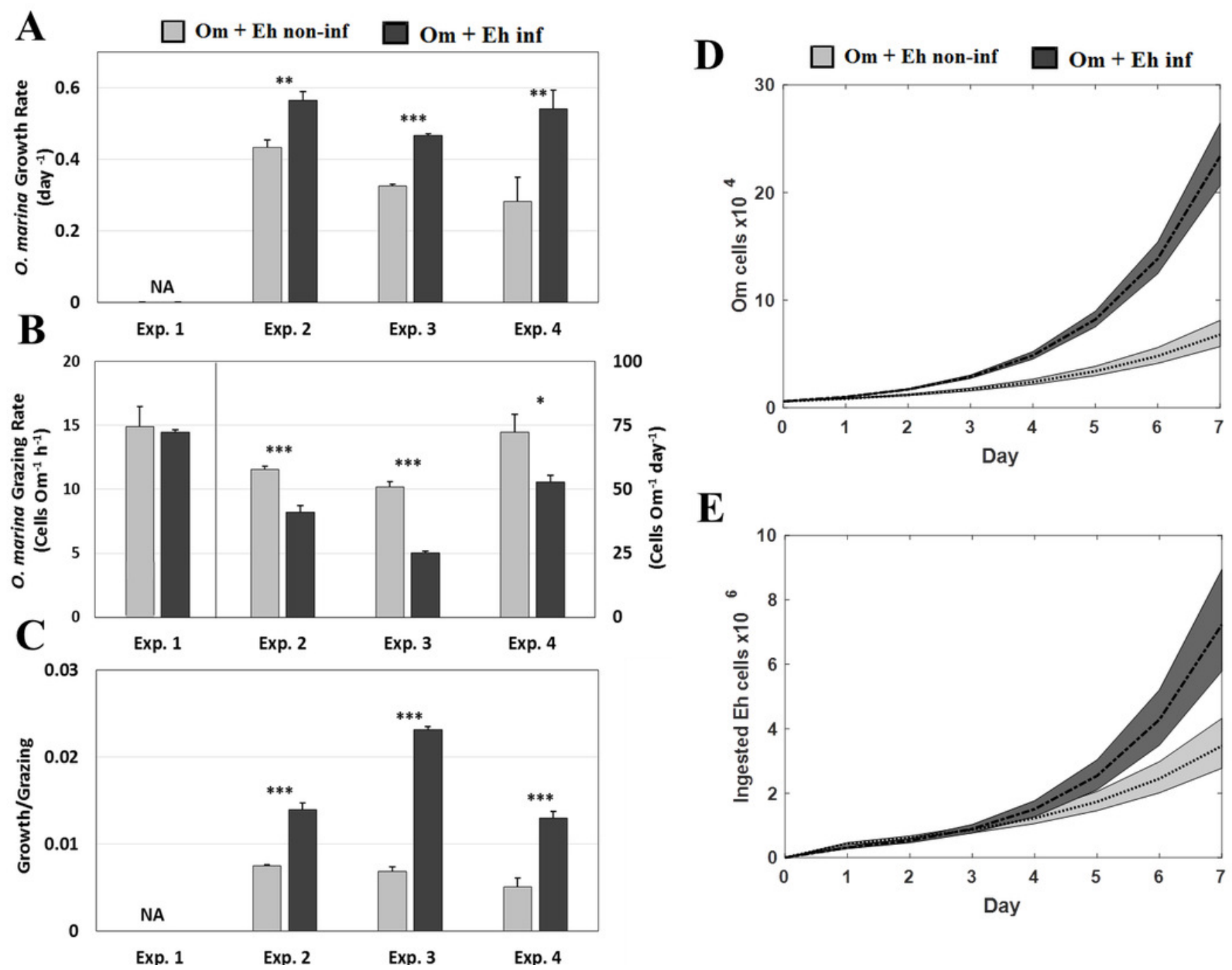


\section{Figure 4}

Differential growth and grazing rates measured in experiment 5 for 0 . marina fed nonaxenic infected $E$. huxleyi versus $<0.4 \mu \mathrm{m}$ filtrate of a non-axenic infected $E$. huxleyi culture.

Fig. 4. Differential growth and grazing rates measured in experiment 5 for $O$. marina fed nonaxenic infected $E$. huxleyi versus $<0.4 \mu \mathrm{m}$ filtrate of a non-axenic infected $E$. huxleyi culture. A: $O$. marina growth rates $\left(\right.$ day $^{-1}$ ). B: $O$. marina grazing of $E$. huxleyi cells (Eh cells $\mathrm{Om}^{-1}$ day $^{-1}$ ). C: 0 . marina grazing of bacteria cells (Bact cells $\mathrm{Om}^{-1}$ day $^{-1}$ ). Values mean \pm one standard deviation. nd denotes "none detected". Asterisks indicate statistical significance: $* * * p<0.001, * * p<0.01$. 
A

Om + Eh inf $\mathbb{N O m}+<0.4 \mu \mathrm{m}$ filt

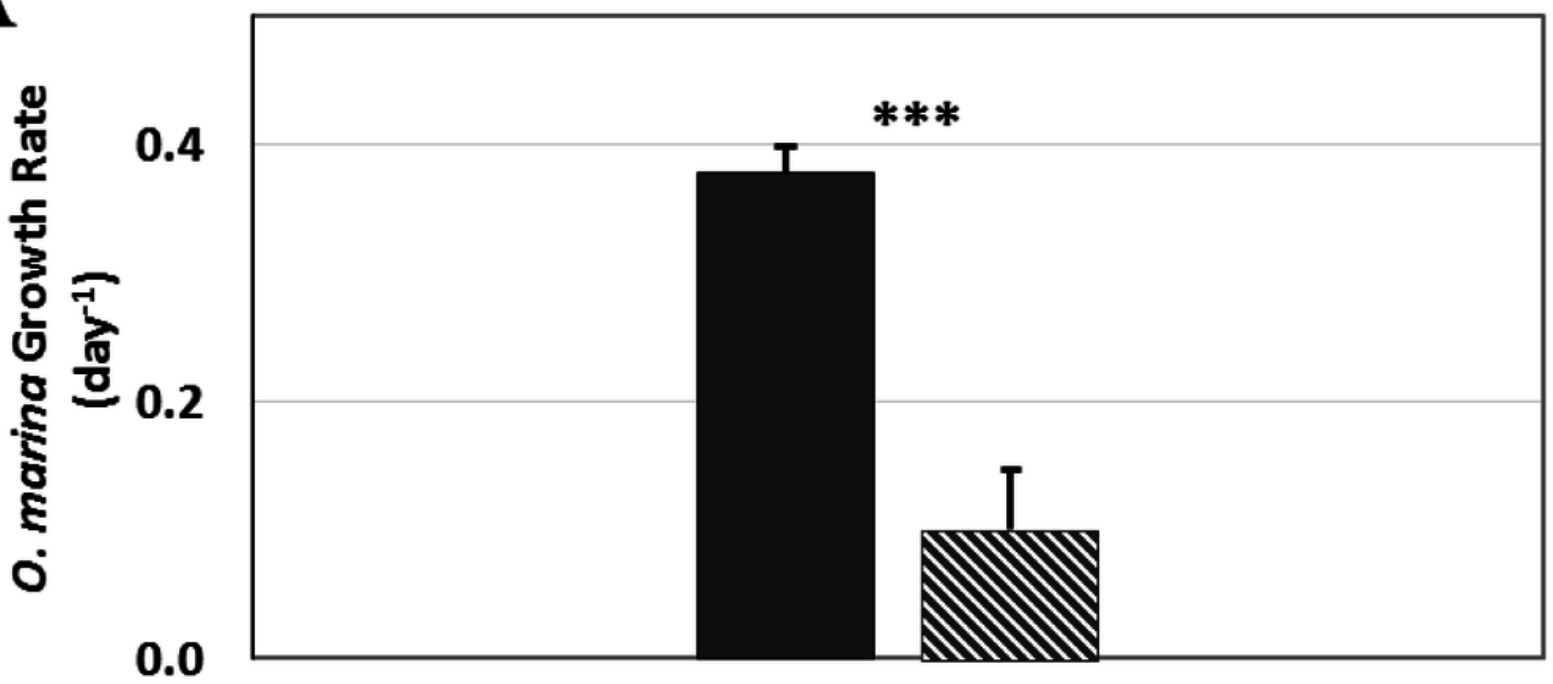

B
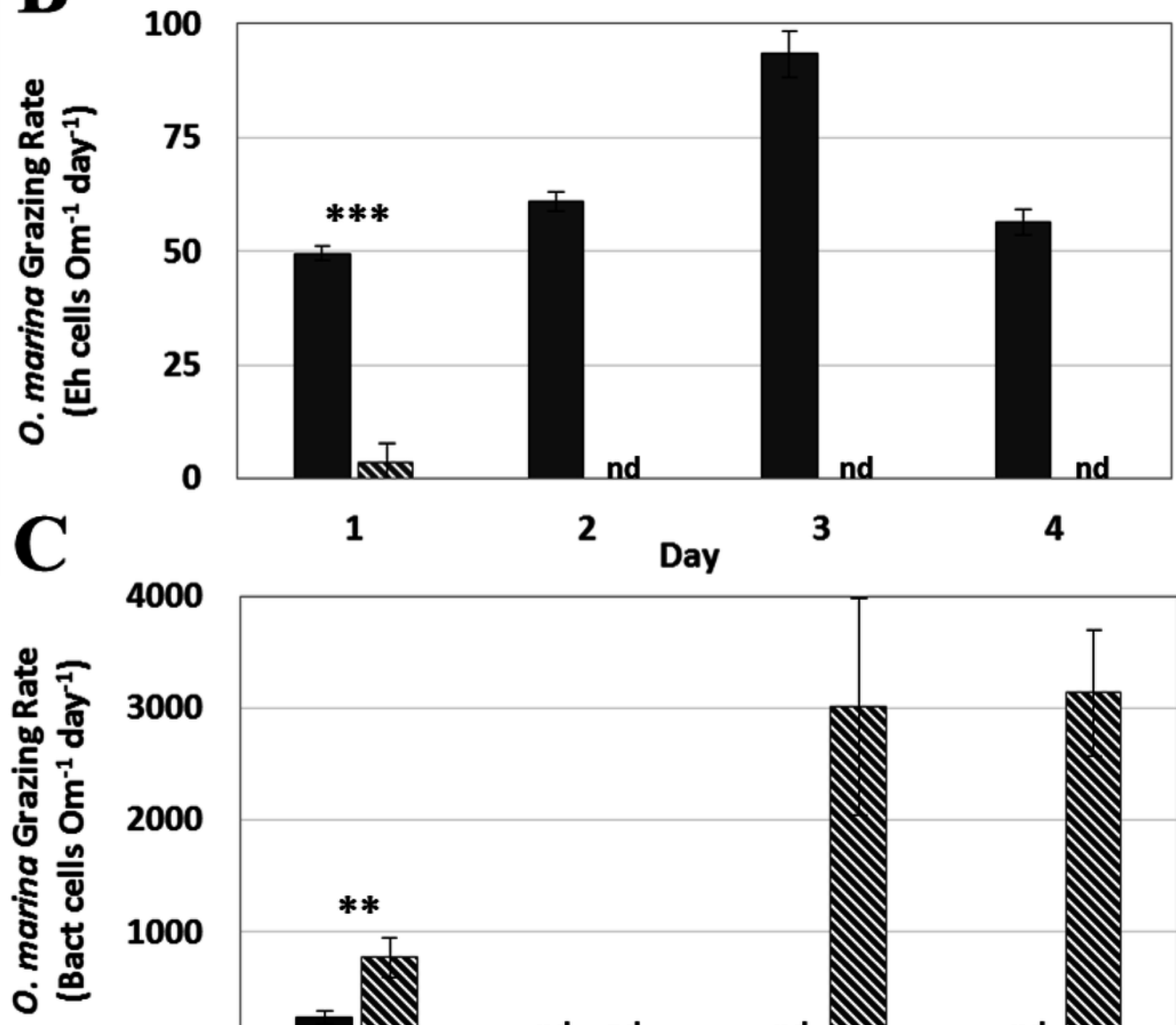

$\mathbf{0}$

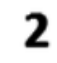

3

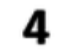

Day

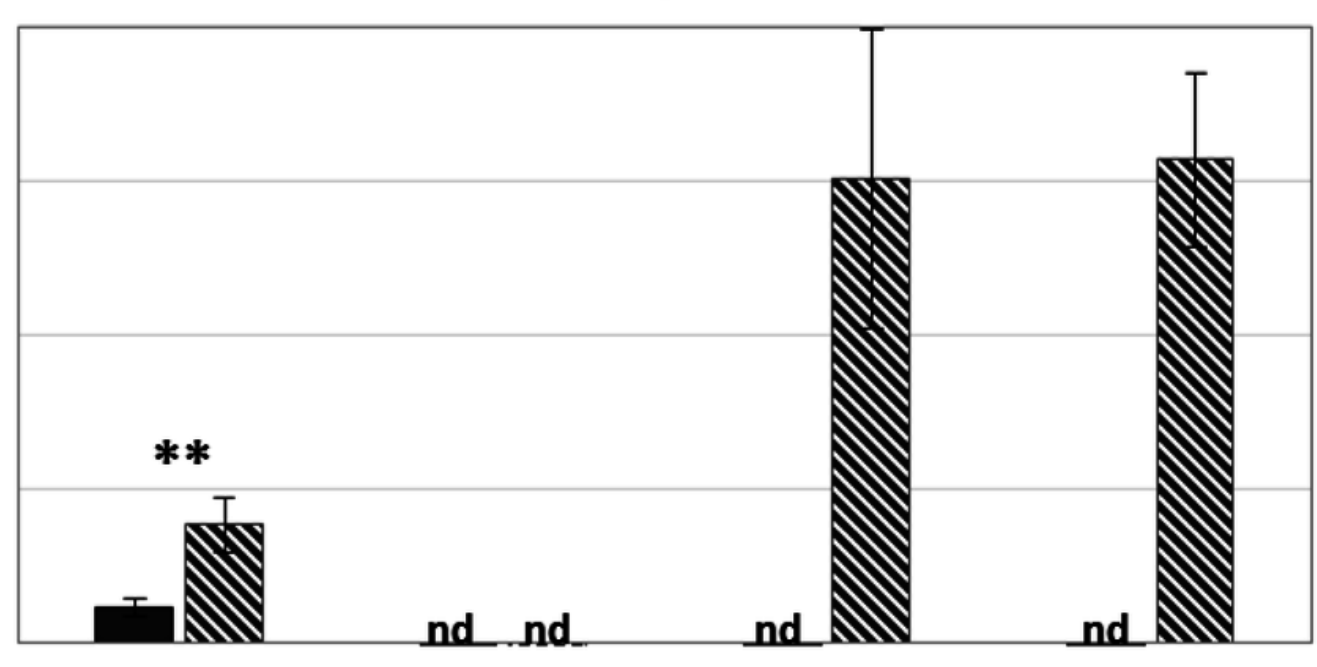




\section{Table $\mathbf{1}$ (on next page)}

Table 1. Details of experiments performed.

Emiliania huxleyi (Eh); Oxyrrhis marina $(\mathrm{Om})$; o indicates that the grazing rates were calculated using $E$. huxleyi k-values from non-grazing controls in experiment 2. 
1 Table 1. Details of experiments performed.

\begin{tabular}{|c|c|c|c|c|c|c|c|c|c|}
\hline & \multicolumn{5}{|c|}{ Experimental Conditions } & \multicolumn{4}{|c|}{ Parameters Measured (Om) } \\
\hline & $\begin{array}{l}\text { EhV: Eh } \\
\quad \text { ratio }\end{array}$ & $\begin{array}{c}\% \% \\
\text { infected } \\
\text { Eh cells } \\
6 \text { h p.i. }\end{array}$ & $\begin{array}{l}\text { Eh:Om } \\
\text { ratio }\end{array}$ & $\begin{array}{l}\text { Initial Om } \\
\text { (cells/ml) }\end{array}$ & $\begin{array}{l}\text { Duration } \\
\text { (days) }\end{array}$ & $\begin{array}{c}\text { Growth } \\
\text { Rate }\end{array}$ & $\begin{array}{l}\text { Grazing } \\
\text { Rate }\end{array}$ & $\begin{array}{l}\text { Fatty } \\
\text { Acids }\end{array}$ & $\begin{array}{l}\text { Cell } \\
\text { Vol }\end{array}$ \\
\hline Experiment 1 & $100: 1$ & 20 & $30: 1$ & 6000 & 0.25 & & $\mathrm{x}$ & & \\
\hline Experiment 2 & $100: 1$ & 20 & $100: 1$ & 4500 & 3 & $\mathrm{x}$ & $\mathrm{x}$ & $\mathrm{X}$ & \\
\hline Experiment 3 & $100: 1$ & 20 & $100: 1$ & 4000 & 7 & $\mathrm{x}$ & o & & \\
\hline Experiment 4 & $50: 1$ & 36 & $100: 1$ & 6000 & 4 & $\mathrm{x}$ & $\mathrm{x}$ & & $\mathrm{x}$ \\
\hline Experiment 5 & $50: 1$ & 34 & $100: 1$ & 6000 & 4 & $\mathrm{x}$ & $\mathrm{x}$ & & \\
\hline
\end{tabular}

2 Emiliania huxleyi (Eh); Oxyrrhis marina (Om); o indicates that the grazing rates were calculated using E. huxleyi kvalues from non-grazing controls in experiment 2. 


\section{Table 2 (on next page)}

Percentage (\%) of individual fatty acids to total FA concentration of cultures

Percentage (\%) of individual fatty acids to total FA concentration of cultures in which: i) 0 . marina was depleted of prey at the start of the experiments (Day $0 \mathrm{Om}$ ); ii) the E. huxleyi cultures fed to O. marina; iii) after three days fed non-infected E. huxleyi (Om + Eh non-inf); and iv) after 3 days fed infected $E$. huxleyi (Om +Eh inf). Values are mean \pm one standard deviation, $n=4, n=4, n=3$ and $n=3$, respectively. Note the values for $E$. huxleyi are the average of duplicate non-infected and duplicate infected cultures. Significant differences in the proportions of individual compounds are shown as: ${ }^{a}$ Day 0 Om vs. E.huxleyi; ${ }^{\text {b }}$ Day 0 Om vs. Day 3 Om + Eh non-inf; ' Day 0 Om vs. Day 3 Om + Eh inf; and ${ }^{d}$ Day 0 Om vs. Day 3 Om + Eh non-inf vs. Day 0 Om vs. Day 3 Om + Eh inf. 
1 Table 2. Percentage (\%) of individual fatty acids to total FA concentration of cultures in which:

2 i) O. marina was depleted of prey at the start of the experiments (Day $0 \mathrm{Om}$ ); ii) the E. huxleyi

3 cultures fed to O. marina; iii) after three days fed non-infected E. huxleyi (Om + Eh non-inf);

4 and iv) after 3 days fed infected E. huxleyi $(\mathrm{Om}+$ Eh inf). Values are mean \pm one standard

5 deviation, $\mathrm{n}=4, \mathrm{n}=4, \mathrm{n}=3$ and $\mathrm{n}=3$, respectively. Note the values for E. huxleyi are the

6 average of duplicate non-infected and duplicate infected cultures. Significant differences in the

7 proportions of individual compounds are shown as: ${ }^{\text {a }}$ Day 0 Om vs. E.huxleyi; b Day 0 Om vs.

8 Day 3 Om + Eh non-inf; ${ }^{c}$ Day 0 Om vs. Day 3 Om + Eh inf; and d Day 0 Om vs. Day 3 Om + Eh

9 non-inf vs. Day 0 Om vs. Day 3 Om + Eh inf.

\begin{tabular}{|c|c|c|c|c|c|}
\hline & FA Class & $\begin{array}{c}\text { Day } 0 \\
\text { Om }\end{array}$ & E. huxleyi & $\begin{array}{c}\text { Day } 3 \\
\text { Om + Eh non-inf }\end{array}$ & $\begin{array}{c}\text { Day } 3 \\
\text { Om + Eh inf }\end{array}$ \\
\hline \multirow{8}{*}{ SFA } & C14:0 & $0.2 \pm 0.2$ & $0.2 \pm 0.1$ & $0.4 \pm 0.1$ & $1.2 \pm 1.3$ \\
\hline & C15:0 & $0.4 \pm 0.3$ & $0.3 \pm 0.2$ & $0.5 \pm 0.0$ & $0.8 \pm 0.4$ \\
\hline & C16:0 & $30.9 \pm 4.5$ & $27.6 \pm 3.6$ & $29.4 \pm 7.6$ & $24.6 \pm 2.6$ \\
\hline & C17:0 & $2.7 \pm 0.1$ & $2.7 \pm 0.7$ & $2.7 \pm 0.3$ & $3.2 \pm 0.1^{\mathrm{c}, \mathrm{d}}$ \\
\hline & C18:0 & $36.2 \pm 11.1$ & $60.9 \pm 7.6^{\mathrm{a}}$ & $46.9 \pm 6.4$ & $56.4 \pm 7.1^{\mathrm{c}}$ \\
\hline & C20:0 & $1.1 \pm 0.1$ & $1.3 \pm 0.3$ & $1.5 \pm 0.8$ & $1.2 \pm 0.4$ \\
\hline & C22:0 & $0.8 \pm 0.2$ & $0.7 \pm 0.6$ & $3.3 \pm 2.3$ & $1.8 \pm 0.9$ \\
\hline & C24:0 & $0.7 \pm 0.5$ & $1.1 \pm 0.1$ & $0.6 \pm 0.4$ & $0.4 \pm 0.3$ \\
\hline \multirow{4}{*}{ MUFA } & C16:1 & $0.8 \pm 1.6$ & 0.0 & 0.0 & 0.0 \\
\hline & C18:1(n-9cis) & $5.0 \pm 4.0$ & $0.0^{\mathrm{a}}$ & $1.6 \pm 1.4^{b}$ & $1.6 \pm 1.6^{\mathrm{c}}$ \\
\hline & C18:1(n-9trans) & $4.6 \pm 3.3$ & $0.0^{\mathrm{a}}$ & $1.7 \pm 1.5$ & $1.3 \pm 1.2$ \\
\hline & C22:1 & $1.1 \pm 0.9$ & $0.1 \pm 0.1$ & 0.0 & 0.0 \\
\hline \multirow{7}{*}{ PUFA } & C18:2 & $2.7 \pm 1.4$ & 0.0 & $0.0^{\mathrm{b}}$ & $0.2 \pm 0.3^{\mathrm{c}}$ \\
\hline & C20:2 & $2.9 \pm 2.3$ & $5.0 \pm 3.7$ & $7.1 \pm 1.9^{b}$ & $3.2 \pm 1.3^{\mathrm{c}, \mathrm{d}}$ \\
\hline & C20:5 (n-3) & $1.2 \pm 1.2$ & $0.1 \pm 0.1$ & $0.2 \pm 0.3$ & $0.3 \pm 0.3$ \\
\hline & C22:6 (n-3) & $8.6 \pm 7.7$ & 0.0 & $4.0 \pm 4.1$ & $3.9 \pm 3.3$ \\
\hline & $\sum$ SFA & $73 \pm 15$ & $95 \pm 4^{\mathrm{a}}$ & $86 \pm 9$ & $89 \pm 6$ \\
\hline & $\sum$ MUFA & $12 \pm 8$ & $0.1 \pm 0.1^{\mathrm{a}}$ & $3 \pm 3$ & $3 \pm 3$ \\
\hline & $\sum$ PUFA & $15 \pm 8$ & $5 \pm 4$ & $11 \pm 6$ & $8 \pm 3$ \\
\hline
\end{tabular}




\section{Table 3(on next page)}

Table 3. Cell volumes $\left(\mu \mathrm{m}^{3}\right)$ of $O$. marina fed non-infected and infected $E$. huxleyi over three days during experiment 4.

Oxyrrhis marina (Om); prey-depleted (prey-depl), i.e., not fed for three days; Emiliania huxleyi non-infected (Eh non-inf); Emiliania huxleyi infected with EhV-86 (Eh inf). Values are mean \pm one standard deviation. 
1 Table 3. Cell volumes $\left(\mu \mathrm{m}^{3}\right)$ of $O$. marina fed non-infected and infected E. huxleyi over three

2 days during experiment 4.

\begin{tabular}{|c|c|c|c|}
\hline Treatment & Day & Replicate & Volume $\left(\mu \mathrm{m}^{3}\right)$ \\
\hline Om prey-depl & 0 & & $5586 \pm 917$ \\
\hline \multirow{9}{*}{ Om + Eh non-inf } & \multirow{3}{*}{1} & A & $4723 \pm 1535$ \\
\hline & & B & $5759 \pm 1123$ \\
\hline & & $\mathrm{C}$ & $5696 \pm 1842$ \\
\hline & \multirow{3}{*}{2} & A & $4107 \pm 1689$ \\
\hline & & $\mathrm{B}$ & $3801 \pm 660$ \\
\hline & & $\mathrm{C}$ & $5602 \pm 1045$ \\
\hline & \multirow{3}{*}{3} & A & $4675 \pm 1141$ \\
\hline & & $\mathrm{B}$ & $4038 \pm 1319$ \\
\hline & & $\mathrm{C}$ & $3949 \pm 977$ \\
\hline \multirow{9}{*}{$\mathrm{Om}+$ Eh inf } & \multirow{3}{*}{1} & A & $5004 \pm 1245$ \\
\hline & & B & $4286 \pm 1053$ \\
\hline & & $\mathrm{C}$ & $4829 \pm 1435$ \\
\hline & \multirow{3}{*}{2} & A & $6105 \pm 462$ \\
\hline & & $\mathrm{B}$ & $5561 \pm 1483$ \\
\hline & & $\mathrm{C}$ & $6977 \pm 1371$ \\
\hline & \multirow{3}{*}{3} & A & $4267 \pm 1218$ \\
\hline & & B & $4478 \pm 1184$ \\
\hline & & $\mathrm{C}$ & $5527 \pm 1956$ \\
\hline
\end{tabular}

3 Oxyrrhis marina (Om); prey-depleted (prey-depl), i.e., not fed for three days; Emiliania huxleyi non-infected (Eh

4 non-inf); Emiliania huxleyi infected with EhV-86 (Eh inf). Values are mean \pm one standard deviation.

5

6

7

8

9

10

11

12

13

14 